Review

\title{
Homo- and Hetero-Oligonuclear Complexes of Platinum Group Metals (PGM) Coordinated by Imine Schiff Base Ligands
}

\author{
Barbara Miroslaw \\ Department of General and Coordination Chemistry and Crystallography, Institute of Chemical Sciences, \\ Faculty of Chemistry, Maria Curie-Sklodowska University in Lublin, Pl. Marii Curie-Sklodowskiej 3, \\ 20-031 Lublin, Poland; barbara.miroslaw@poczta.umcs.lublin.pl; Tel.: +48-815-375-582
}

Received: 30 April 2020; Accepted: 13 May 2020; Published: 15 May 2020

\begin{abstract}
Chemistry of Schiff base (SB) ligands began in 1864 due to the discovery made by Hugo Schiff (Schiff, H., Justus Liebigs Ann. der Chemie 1864, 131 (1), 118-119). However, there is still a vivid interest in coordination compounds based on imine ligands. The aim of this paper is to review the most recent concepts on construction of homo- and hetero-oligonuclear Schiff base coordination compounds narrowed down to the less frequently considered complexes of platinum group metals (PGM). The combination of SB and PGM in oligonuclear entities has several advantages over mononuclear or polynuclear species. Such complexes usually exhibit better electroluminescent, magnetic and/or catalytic properties than mononuclear ones due to intermetallic interactions and frequently have better solubility than polymers. Various construction strategies of oligodentate imine ligands for coordination of PGM are surveyed including simple imine ligands, non-innocent 1,2-diimines, chelating imine systems with additional N/O/S atoms, classic $\mathrm{N}_{2} \mathrm{O}_{2}$-compartmental Schiff bases and their modifications resulting in acyclic fused ligands, macrocycles such as calixsalens, metallohelical structures, nano-sized molecular wheels and hybrid materials incorporating mesoionic species. Co-crystallization and formation of metallophilic interactions to extend the mononuclear entities up to oligonuclear coordination species are also discussed.
\end{abstract}

Keywords: oligonuclear complexes; platinum group metals; PGM; Schiff base; imine ligand; coordination compound

\section{Introduction}

The present paper focuses on homo- and hetero-oligonuclear Schiff base (SB) complexes of platinum group metals (PGM), which are rarely considered in numerous comprehensive reviews despite of their great importance.

The reaction between carbonyl compound and primary amine discovered by Hugo Schiff in 1864 [1] gave basis for further research in various scientific fields and resulted in thousands of papers being submitted by scientists all over the world to a diverse spectrum of scientific magazines. Over the past 10 years, approximately 2000 new papers were published annually according to Scopus document search (Figure 1). The reports cover synthesis of new organic and coordination compounds, their luminescent, magnetic, catalytic or bioactive properties up to advanced applications in many industries such as dye-sensitized solar cells. Although the topic seems to be quite old and exploited, several scientific groups worldwide are still studying the great potential of this group of compounds finding new applications for the imine based ligands and their complexes. The azomethine molecular fragment is used as a structural element for the synthesis of polydentate ligands of various structures up to mechanically interlocked molecular architectures such as metallacycles, cages or knots [2-4]. 


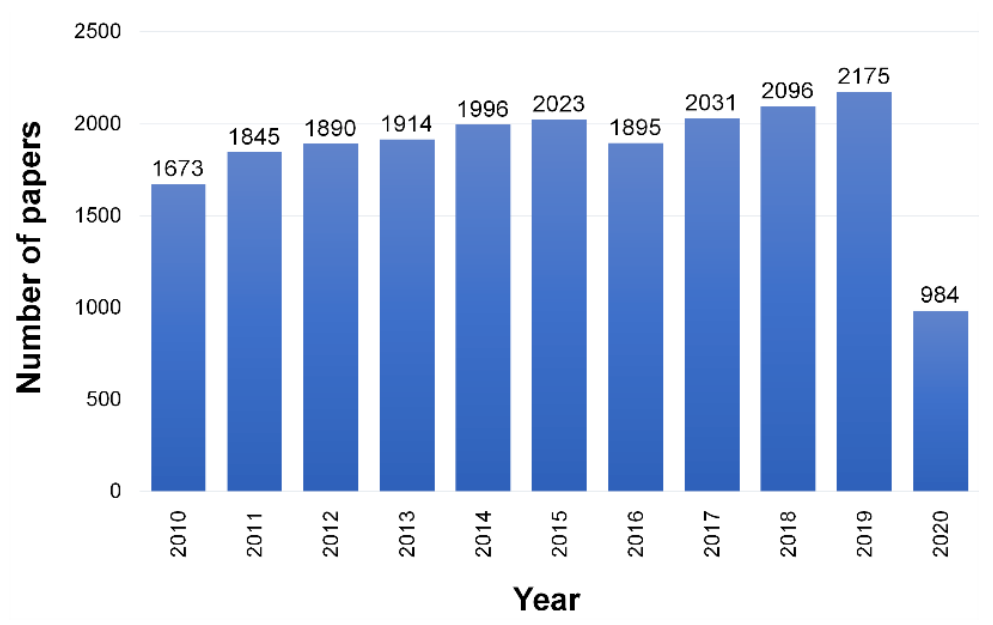

Figure 1. Number of papers published per year with the concept "Schiff base" in the title, abstract or keyword section according to Scopus document search in the period of the last 10 years (data retrieved on 08 May 2020).

Worth recommending are excellent reviews on life and work of Hugo Schiff $[5,6]$ who was not only a formidable scientist but also an interesting personality actively engaged in civic and political life. For a better insight into this section of chemistry, it is worth to refer to comprehensive reviews on chemistry and general information on imines, which were widely summarized by Layer [7] and more recently by other scientific groups [8-13]. Zoubi et al. reported the recent progress in thermal analysis of Schiff base [14].

\subsection{Synthesis Methods of Schiff Base Ligands and Their Complexes}

The classic synthesis method of Schiff bases (SB) is a condensation of carbonyl compound with primary amine carried out in solution, where solvents are usually organic compounds forming azeotropic mixtures. This method allows one to construct ligands ranging from small molecules up to macrocyclic species and covalent organic-frameworks based on SB chemistry [9,15-19]. The mechanism of SB formation and hydrolysis was discussed in details by Cordes and Jencks [20]. Water is regarded as a disturbing factor inhibiting the progress of the chemical reaction, which can be eliminated by molecular sieves [21], or dehydrating agents acting as catalysts such as phosphorous(V) oxide supported on silica [22], magnesium perchlorate [23], titanium(IV) chloride [24], aluminum chloride [25] and hydrobromic acid [26]. Apart from conventional methods, there are also more sophisticated ones, including green chemistry methods with synthesis performed in water suspension medium [27] or under solvent-free conditions supported by using the microwave irradiation [28] and montmorillonite $\mathrm{K} 10$ clay [29] or tungsten(VI) chloride as [30] catalyst, or on alumina surface [31]. Rao et al. reported an eco-friendly synthesis method in aqueous medium [32]. Among reports on synthesis of SB worth mentioning are the methods performed in ionic liquids [33], techniques with the use of ordered mesoporous materials [34], solvent free synthesis reaction performed under infrared [35], ultrasound [36] and microwave irradiation [37]. Direct synthesis mechanochemical methods are also applied to perform solid-solid synthesis [38-40] confirming the high reactivity of this group of compounds.

The synthesis of coordination compounds of SBs may be performed in a stepwise manner, i.e., first synthesis of the SB ligand and subsequently the synthesis of the complex [41,42]. The modular "chemistry on complex" approach can be applied with the use of metal cross-coupling reactions [43]. However, frequently the obtaining of ligands and complexes may be conducted in situ by one-pot reaction with simultaneous addition of SB substrates and metal salts resulting in simple self-assembling of $\mathrm{N}_{2} \mathrm{O}_{2}$ compartmental SB coordination units [44] up to macrocyclic calixsalens [45]. The metallic species may play a catalytic and template role in such syntheses. The details of many interesting and efficient synthesis methods for SB complexes can be found in the cited research reports. 


\subsection{Importance and Application of Schiff base Ligands and Their Complexes}

SBs play a crucial role in catalytic mechanisms of biologically important proteins [46]. There are also reports on Schiff base acting as an intermediate in the Maillard reaction resulting in the formation of Amadori or Heyns products such as acrylamide from sugars and amino acids during high-temperature cooking processes (i.e., frying, roasting or baking). This type of rearrangement reactions may be responsible for the pathological effects of diabetes, Alzheimer's disease and ageing processes in general [47-50].

Imine compounds and their metal complexes exhibit a broad range of biological activities such as anti-inflammatory, antiviral, antifungal, antibacterial, antimalarial, antiproliferative, antipyretic properties, etc. The excellent reviews on biological activities of SBs can be found in the following references [51-58]. SB complexes can be used as urease inhibitors [59]. Sztanke et al. summarized the antiprolife activity of azomethine derivatives [60]. The SBs are recognized as a versatile pharmacophore [57]. Polynuclear salen-mesoionic carbene hybrid complexes have application as biomedical hydrogels [61]. The complexes of Schiff bases with lanthanides find many applications for example as a contrast media for magnetic resonance imaging or in the therapy of neoplastic diseases [62]. Majid et al. reviewed the capability of SB complexes to enhance the transport across the biomembrane [63].

Many compelling reviews report on versatile applications of SBs and their complexes $[13,64]$. Catalysis is another field of application of SB ligand and their complexes. Many SB complexes show excellent catalytic activity and can be used in organic synthesis [12,54,65-70]. SBs can be applied for solvent extraction of metal ions [71-73]. Schiff Bases and their transition metal complexes are applied as an efficient optical chemical [74-76] or electrochemical sensors for detection of analytes in forensic, pharmaceutical and environmental samples [74,77-80]. Oligonuclear PGM complexes are assessed as prospective phosphorescent emitters in organic light-emitting diodes (OLEDs) [81]. The SB compounds are also used in nanotechnology as coatings for chemical sensing [82] and as supramolecular sensing materials for preparation of potentiometric membrane sensors [83]. The complexes of SBs are applied for production of dye-sensitized solar cells [84-87]. The utilization of SB complexes including PGM oligomers as energy storage materials for batteries and supercapacitors was summarized by Zhang [88].

\subsection{Schiff base Ligands in Coordination Chemistry}

Due to excellent ligating properties and relatively facile synthesis methods the imine based ligands are widely used in transition metal coordination chemistry. A collection of interesting papers on SB metal complexes was published recently in special issues in Inorganics edited by Professor Dr. Santo Di Bella and in Molecules edited by Professor Dr. Antonella Dalla Cort [89,90]. Jain and Jain published a comprehensive review in 2005 with nearly two thousand of references exclusively on binuclear palladium(II) and platinum(II) complexes [91]. Golbedaghi and Fausto reviewed the cocrystal formation of SBs [92] together with their application in pharmaceutical, paper, textile, photographic and electronic industries. Beck and Sünkel surveyed the most recent achievements in coordination compounds of bidentate indigo related ligands [93]. Multi-metallic salen complexes were described by Mondal and Chattopadhyay [94] and penta-, hexa- and heptadentate SBs by Liu and Hamon [12,13]. Karmakar and Chattopadhyay presented the stereochemistry of tetradentate $\mathrm{N}_{2} \mathrm{O}_{2}$ donor Schiff base ligands in octahedral complexes [95]. However, the authors focused on trivalent $3 \mathrm{~d}$ metals. The structural aspects of SB and their complexes can be found in excellent reviews for example on multi-metallic salen [94], arene based complexes [96] and salicylaldehyde [97] complexes, or on actinoid oligonuclear complexes of SB ligands [98]. Liu and Hamon summarized the penta-, hexa- and heptadentate SB ligands and their complexes [13]. The SB ligands were also studied in the macrocyclic forms of multidentate aza, oxoaza or thiaaza heterocyclic compounds [16] or oligo- and oligometalloporphyrins [99]. Additionally, the tautomerism of SBs and possibility of hydrogen bond or stacking interaction formation was studied intensively together with layer-by-layer (LbL) assembly for many applications [100-108].

There were published many reviews on Schiff base ligands and their coordination compounds. However, oligonuclear SB coordination compounds with PGMs are much less often taken into 
consideration and frequently omitted in discussions. The current manuscript focuses on this particular interesting combination of imine ligands and platinum group metals (i.e., $\mathrm{Ru}, \mathrm{Rh}, \mathrm{Pd}, \mathrm{Os}$, $\mathrm{Ir}$ and $\mathrm{Pt}$ ) collecting in one paper the most recent and important advances in this field.

Due to the extraordinary catalytic, luminescent and magnetic properties of this unique group of compounds the perspective application of oligonuclear SB-PGM materials in modern technology is versatile.

This review focuses on the significant reports on obtaining oligonuclear SB-PGM materials published over the past ten years, i.e., 2010-2020. However, some earlier studies (down to 1980) were also included because of their importance. This review may offer a support in the rational design and construction of new oligonuclear platinum group metal coordination compounds incorporating Schiff base building blocks for high tech applications in material science as energy or gas storage materials, in catalysis, electrochemical or luminescent sensors and/or for biomedical usage.

\section{Results and Discussion}

\subsection{Strategies on Construction of Oligonulear Schiff Base Complexes of Platinum Group Metals}

The present review is divided into eight sections related to various structural approaches to obtain homo- and hetero-oligonuclear coordination PGM compounds incorporating imine ligating sites. In the first section the use of simple imine as a monodentate or bridging ligand is discussed. Then following section surveys the unusual behavior of non-innocent 1,2-diimine related ligands, which may ligate both in a $\sigma$ - and $\pi$-fashion. Next, the examples are given on combining the imine group with additional ligating $\mathrm{N} / \mathrm{O} / \mathrm{S}$ atoms affording coordination chelating pockets. The usage of widely studied $\mathrm{N}_{2} \mathrm{O}_{2}$ Schiff base compartmental ligands is summarized in the next section. Apart from classic bi- or trinuclear PGM systems based on $\mathrm{N}_{2} \mathrm{O}_{2}$ compartment $\mathrm{SB}$ ligands, the concept of utilization this system as building blocks for the construction of oligodentate species in the form of expanded voluminous molecules, macrocycles, tweezers or knots is presented.

The last sections show the approach to application of auxiliary linking ligands, cocrystals formation and utilization of metallophilic interactions to increase the nuclearity of Schiff base related PGM coordination compounds.

The extensive topic of ligands with imine group built in cyclic species such as azoles, purine bases, porphyrins, etc. was excluded from this review due to vast literature in this field.

The summarized coordination modes of imine, non-innocent 1,2-diimine, coordination chelating pockets based on azomethine and additional N/O/S ligating atoms and $\mathrm{N}_{2} \mathrm{O}_{2}$ Schiff base compartmental ligands are presented in Schemes 1 and 2.

\subsection{Imine as a Monodentate and Bridging Ligand}

The simple imine $\mathrm{C}=\mathrm{N}$ molecular fragment is a powerful key to coordination chemistry (Scheme 1a). The most important advantages of azomethine group in coordination chemistry are (1) simple and efficient synthesis enabling linking of various larger molecular fragments and (2) high affinity to form coordination bonds with all metallic elements. The imine $\mathrm{N}$ atom can act as a monodentate or bridging ligand (Scheme 1b,c) resulting in marvelous structures such as reported by Cook at al. [109]. A unique hexagonal $\mathrm{Pd}_{7}$ nanosheet (Figure 2) was synthesized via the reaction of $\mathrm{PdCl}_{2}\left(\mathrm{PhCN}_{2}\right.$ and $\mathrm{Li}\left(\mathrm{N}=\mathrm{C}^{t} \mathrm{Bu}_{2}\right)$ in THF at low temperature of $-25{ }^{\circ} \mathrm{C}$. The structure creates an opportunity to study the exceptional coordination environment of the central palladium(0) atom. This report shows that ketimines may be effective agents at stabilizing nanoclusters of low-valent transition metals. This structure represents an "Atomically Precise NanoCluster" (APNC), which usually is related to $\mathrm{Au}, \mathrm{Ag}$ and $\mathrm{Cu}$ nanostructures applied for high tech solutions in catalysis, imaging and quantum computing [110-112]. 
<smiles>[R3]N=C([R])[R]</smiles>

(a)<smiles>[R3]N=C([R])C([R2])=[NH+][R3]</smiles>

(d)<smiles>[R]C([R])=C([R])N([R])[R4]</smiles>

(g)

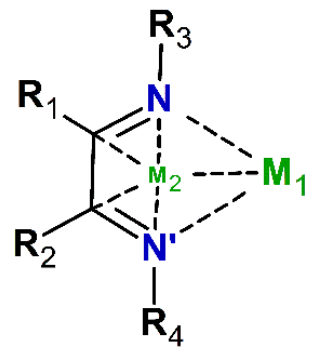

(j)<smiles></smiles>

(b)<smiles>[R]C(C([R])=[N+]([R])[R])=[N+]([R3])[M]</smiles>

(e)<smiles>[R]C([R])=C([R])N([R3])[M]</smiles>

(h)

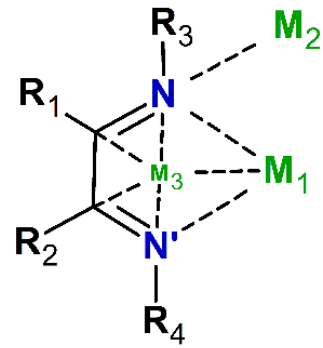

(k)<smiles>[R]C([R])=[N+]([R3])[M]</smiles>

(c)<smiles>[R]C(C([R])=[N+]([R])[R])=[N+]([R3])[R]</smiles>

(f)<smiles>[R]C([R])=[N+]([R4])[N+]([R3])([R3])[M]</smiles>

(i)

Scheme 1. Coordination modes of imine and 1,2-diimine ligands with denticity of ligands described with kappa notation $(\kappa)$ and where necessary hapticity given in eta notation $(\eta)$ : (a) Imine ligand; (b) monodentate 2e $\kappa^{1}$ mode; (c) monoatomic bridging 2e $\mu_{2}-\kappa^{2}$ mode; (d) 1,2-diimine ligands; (e) bidentate bridging $4 \mathrm{e} \mu_{2}-\kappa^{1}: \kappa^{1}$ mode in s-cis 1,2-diimine; (f) bidentate bridging $4 \mathrm{e} \mu_{2}-\kappa^{1}: \kappa^{1}$ mode in s-trans 1,2-diimine; (g) bidentate chelating $4 \mathrm{e} \kappa^{2}-\mathrm{N}_{,} \mathrm{N}^{\prime}$ mode; (h) tridentate chelating bridging $4 \mathrm{e} \mu_{2}-\kappa^{2}: \kappa^{1}$ mode; (i) tetradentate chelating bridging 4 e $\mu_{3}-\kappa^{1}: \kappa^{2}: \kappa^{1}$ mode; (j) 8e $\mu_{2}-\kappa^{2}-\mathrm{N}, \mathrm{N}^{\prime}: \eta^{2}-\mathrm{C}=\mathrm{N}: \eta^{2}-\mathrm{C}^{\prime}=\mathrm{N}^{\prime}$ mode; (k) 8e $\mu_{3}-\kappa^{1}-\mathrm{N}: \kappa^{2}-\mathrm{N}, \mathrm{N}^{\prime}: \eta^{2}-\mathrm{C}=\mathrm{N}: \eta^{2}-\mathrm{C}^{\prime}=\mathrm{N}^{\prime}$ mode; (l) 6 e $\mu_{2}-\kappa^{2}-\mathrm{N}, \mathrm{N}^{\prime}: \eta^{2}-\mathrm{C}^{\prime}=\mathrm{N}^{\prime}$ mode and (m) 6e $\mu_{3}-\kappa^{1}-\mathrm{N}: \kappa^{2}-\mathrm{N}, \mathrm{N}^{\prime}: \kappa^{1}-\mathrm{N}^{\prime}: \eta^{2}-\mathrm{C}^{\prime}=\mathrm{N}^{\prime}$ mode. 
<smiles>[R]C(=C([R])N([R3])C)c1cccc[n+]1C</smiles>

(a)

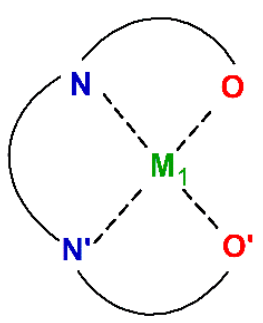

(e)<smiles>[R][NH+]=C([R])c1cccc(C([R4])=[N+]([R3])[R])[n+]1[N-]</smiles>

(b)

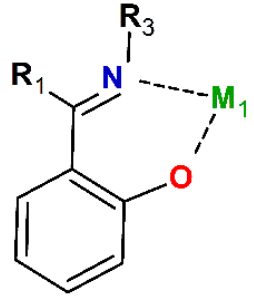

(c)<smiles>[M]Sc1ccccc1C([R3])=C([R3])N</smiles>

(d)

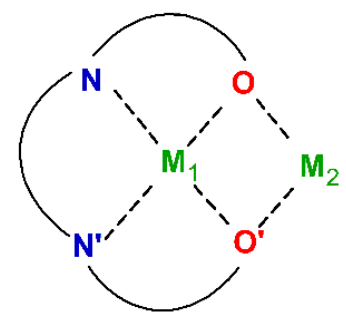

(f)

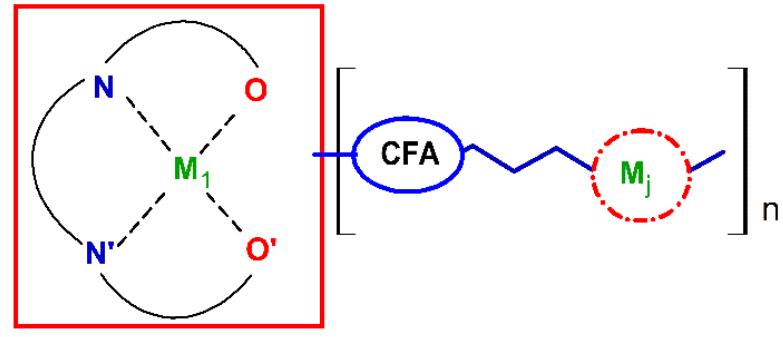

(g)

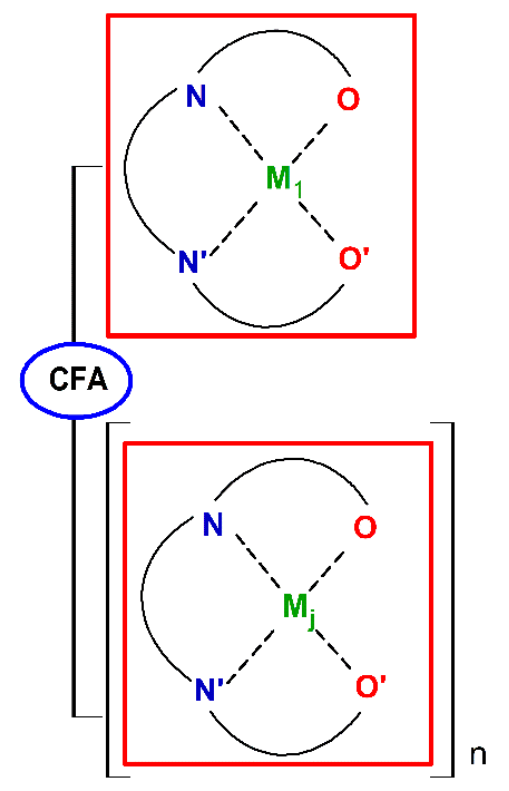

(h)

Scheme 2. (a-d) Coordination chelating pockets made of imine group and additional ligating heteroatom $\mathrm{N} / \mathrm{O} / \mathrm{S}$; (e) scheme of binuclear and (f) trinuclear complex based on $\mathrm{N}_{2} \mathrm{O}_{2}$ compartmental Schiff base ligand; (g) hybrid material made of SB fused by covalently fusing agent (CFA) with additional ligating moieties, $n \geq 1, j \geq 1 ;(\mathbf{h})$ acyclic and (i) cyclic fused SB units resulting in oligodentate ligands.

A simple ketimine ligand may yield complexes coordinated in the $\kappa^{1}-\mathrm{N}$ monodentate mode. An example is a binuclear complex of $\mathrm{Pt}$ with additional activated 1,5-cyclooctadiene fragment acting as a bridge between two metal centers (Figure 3a; MOYJES) [113]. Secondary ketimine ligands were also utilized as monodentate ligands supplementing the coordination sphere in complexes of Rh [114] and Pd [115]. 

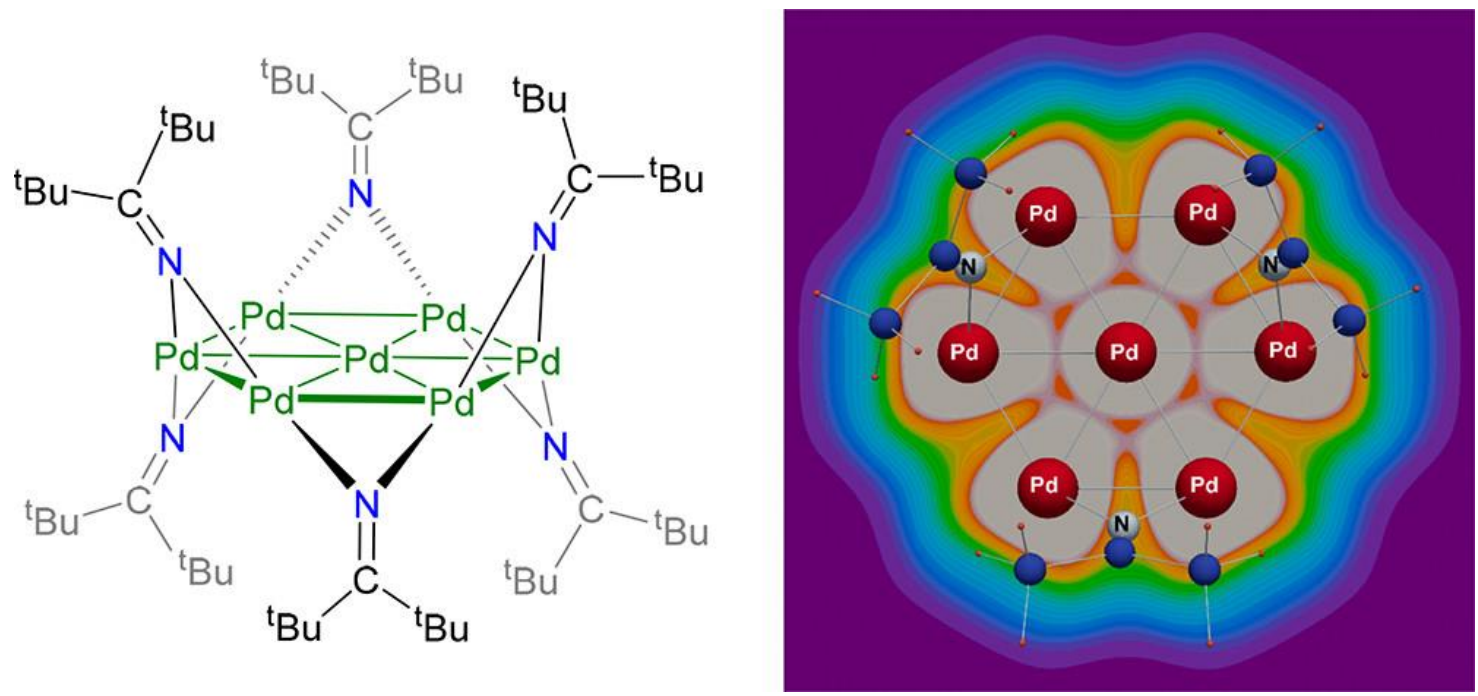

Figure 2. Hexagonal $\mathrm{Pd}_{7}$ nanosheet stabilized by ketimine ligand [109]. Reprinted with permission from A. W. Cook, P. Hrobárik, P. L. Damon, G. Wu, T. W. Hayton, Inorg. Chem. 2020, 59, 2, 1471-1480. Copyright (2020) American Chemical Society (CSD Refcode PIDCID).

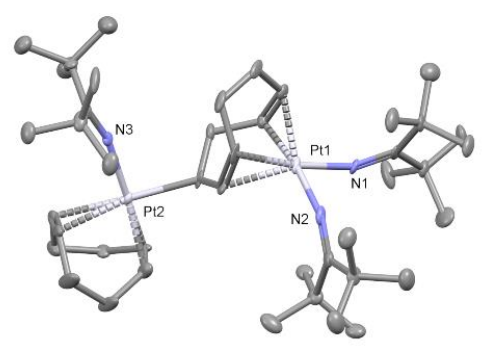

(a)

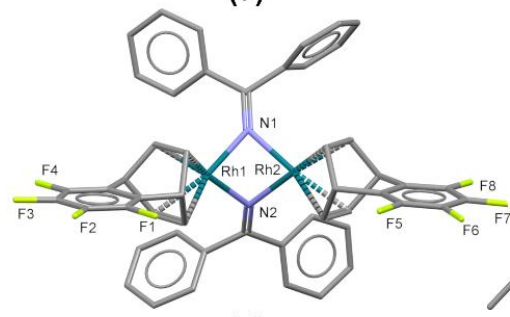

(d)

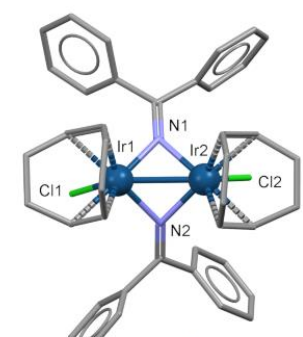

(b)

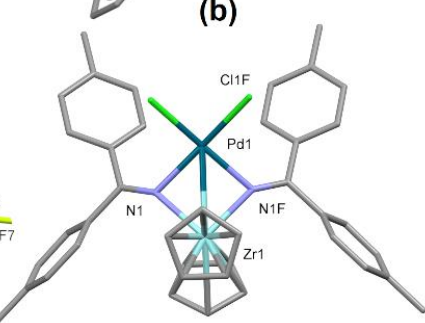

(e)

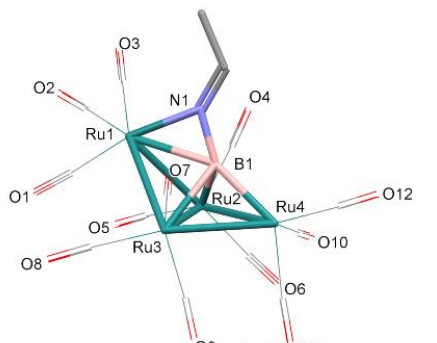

(c) 011

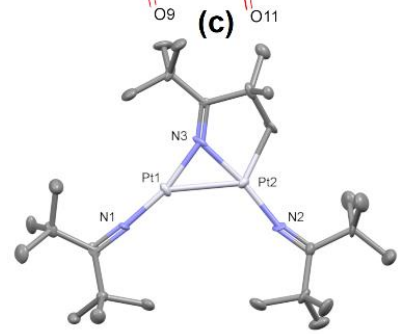

(f)

Figure 3. (a) Binuclear complex of $\mathrm{Pt}(\mathrm{II})$ with monodentate $\kappa^{1}-\mathrm{N}$ ketimine ligands and activated 1,5-cyclooctadiene fragment acting as an intermetallic bridge [113] (CSD Refcode MOYJES); (b) binuclear complex of $\operatorname{Ir}(\mathrm{II})$ with ketimine as an intermetallic bridge and 1,5-cyclooctadiene ligands located on the outside of the coordination unit [116] (CSD Refcode KABLOP); (c) bridging $\mu_{2}-\kappa^{2}$ ethanimine ligand in metallaborane tetra-ruthenium cluster with boron-nitrogen coupling [117] (CSD Refcode PORSUK); (d) binuclear complex of Rh(II) with ketimine bridging ligand [118], shown only one symmetrically independent molecule (CSD Refcode LIFMIW); (e) heterobimetallic Zr/Pd complex with ketimine linkage [119] (CSD Refcode WAGHOC) and (f) binuclear complex of Pt(II) stabilized by ketimine ligand with very short Pt-Pt distance and activated C-H bond [113] (CSD Refcode MOYHUG). Solvent molecules and hydrogen atoms were omitted for clarity.

However, the ketimine fragment may also play a role as a bridging ligand itself. Werner et al. reported a reversed structure with ketimine as a bridge and 1,5-cyclooctadiene located on the outside of the coordination unit (Figure 3b; KABLOP) [116].

A simple bridging $\mu-\kappa^{2}$ ethanimine ligand may also play an auxiliary role as in the case of metallaborane cluster found in the complex of $\left(\mu_{4}\right.$-ethyliminohydridoboron- $\left.H, B, B, B, B, N\right)$ 
-( $\mu_{2}$-hydrido)-dodecacarbonyl-tetra-ruthenium (Figure 3c; PORSUK), which was studied in photolysis. This is also an example of coupling between $\mathrm{N}$ and $\mathrm{B}$ atoms [117].

Ketimine bridging ligands were also used to synthesize complexes of other platinum group metals such as Rh, Ir [118] or Pd [120] (Figure 3d; LIFMIW). Such compounds may be applied for imine-directed aromatic $\mathrm{C}-\mathrm{H}$ bond activation [121].

Kuwabara et al. used the ability of ketimine ligand to form intermetallic bridges for synthesis of very interesting coordination architecture of mixed $\mathrm{Zr} / \mathrm{Pd}$ heterobimetallic complex (Figure 3e; WAGHOC) [119], where the coordination sphere was supplemented by $\eta^{5}$-cyclopentadienyl ligands and chloride anions.

The application of simple ketimine ligand resulted also in the first report on linear $\mathrm{Pt}(\mathrm{II})$ complex of $\mathrm{Pt}\left(\mathrm{N}=\mathrm{C}^{\mathrm{t}} \mathrm{Bu}_{2}\right)_{2}$ and a binuclear byproduct $\left[\left({ }^{\mathrm{t}} \mathrm{Bu}_{2} \mathrm{C}=\mathrm{N}\right) \mathrm{Pt}\left(\mu-\mathrm{N}, \mathrm{C}-\mathrm{N}=\mathrm{C}\left({ }^{\mathrm{t}} \mathrm{Bu}\right) \mathrm{C}(\mathrm{Me})_{2} \mathrm{CH}_{2}\right) \mathrm{Pt}\left(\mathrm{N}=\mathrm{C}^{\mathrm{t}} \mathrm{Bu}_{2}\right)\right]$ with metallophilic interaction giving very short Pt-Pt distance (2.5951(6) $\AA$ ) and activated one of the $t$-butyl C-H bonds (Figure 3f; MOYHUG) [113]. This structure breaks the well-established knowledge on planar tetragonal coordination requirements for the $\mathrm{Pt}(\mathrm{II})$ metal center. Additionally, this binuclear construction shows why the PGM complexes are so special in comparison to other transition metals. They deliver additional tools for crystal engineering in the form of metallophilic interactions and bond formation between metal and $\mathrm{C}$ atoms.

\subsection{Non-innocent 1,2-diimine Ligands Binding in $\sigma$-and $\pi$-fashion}

1,2-Diketimines (Scheme 1d) belong to the group of "non-innocent ligands", which means that in metal complexes their oxidation state is not clear. The non-innocent ligands, when combined with redox-active transition metal ions, can result in redox-tautomeric complexes (Figure 4) [122]. The characteristic feature for these complexes is the intramolecular electron transfer between the coordinated ligand and the metal centers as well as intermetallic electronic interactions [123-126]. Additionally, such complexes may exhibit low-energy electronic transitions (NIR electrochromism) that can be used in optical materials for example as variable optical attenuator $[127,128]$. Kaim published an excellent review on chelate rings formed by non-innocent ligands [129].
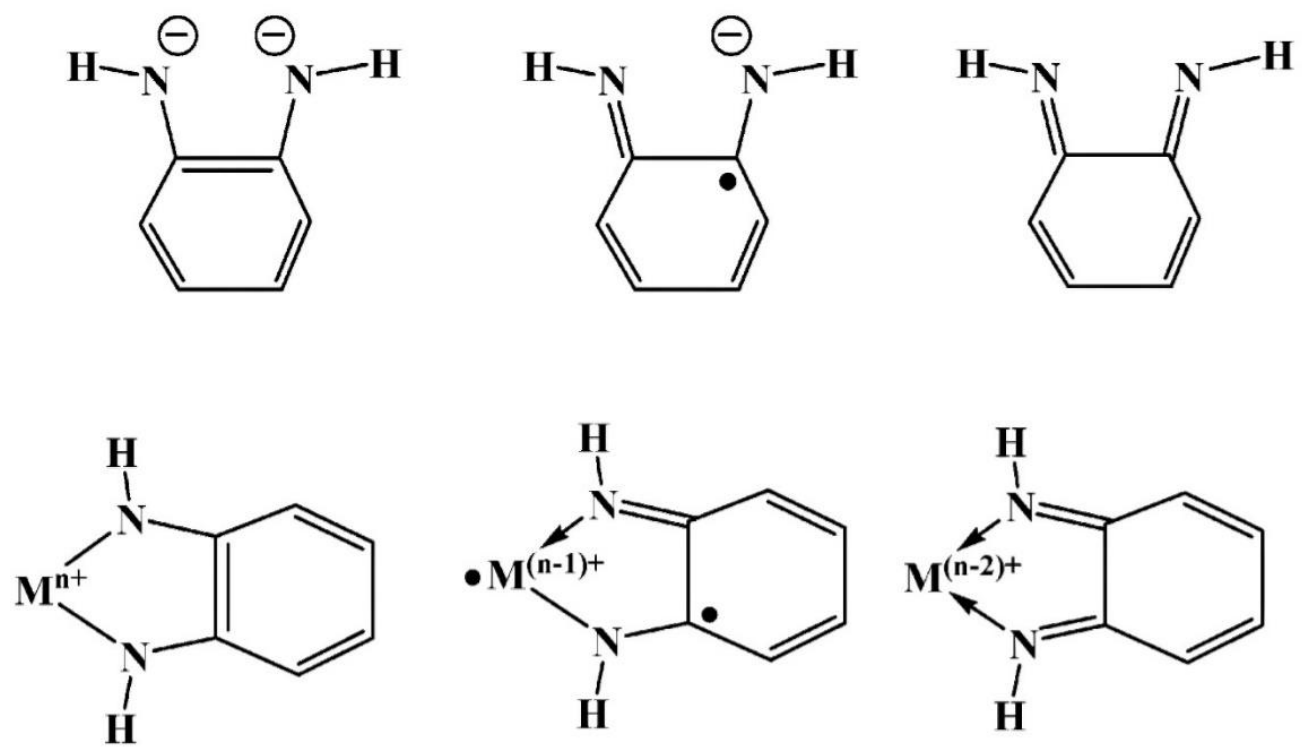

Figure 4. The behavior of non-innocent ligand upon complexation [122]. Reprinted with permission from Anillo, A.; Díaz, M. R.; García-Granda, S.; Obeso-Rosete, R.; Galindo, A.; Ienco, A.; Mealli, C. Structural and electronic rearrangements upon the oxidation of binuclear $\left(\mathrm{Ru}_{2}\right)$ and trinuclear $\left(\mathrm{MoRu}_{2}\right)$ complexes with bridging o-phenylenediamido ligands. Organometallics 2004, 23 (3), 471-481. Copyright (2004) American Chemical Society. 
The application of 1,2-diketimines for synthesis of PGM oligonuclear complexes may result in unusual structures due to the ability of this ligand to bind both via $\sigma$, as well as, $\pi$-bonding (Scheme 1e-m). 1,2-Diimine is a versatile building element used for making bridges between coordination centers. In acyclic entities this type of ligand may have s-cis or s-trans arrangement, which may lead to a different ligating function.

A simple bridging $4 \mathrm{e}$ donor $\mu-\kappa^{1}-\mathrm{N}: \kappa^{1}-\mathrm{N}^{\prime}$ coordination mode of $s$-trans 1,4-diaminobutane (DAB) related ligands is characteristic to many coordination compounds including some platinum group metals [130,131]. The interesting feature found during synthesis of a heterobimetallic palladium-platinum complex with such bridging $4 \mathrm{e}$ donor $\sigma, \sigma-\mathrm{N}, \mathrm{N}^{\prime}$ coordination fashion is the preservation of 1:1 Pd:Pt ratio in the crystal structure although due to the reported disorder in metal positions the authors did not preclude the coexistence of homo-dimeric $\mathrm{Pd}_{2}$ and $\mathrm{Pt}_{2}$ species in the same crystal structure (Figure 5a; FACKAV) [132].

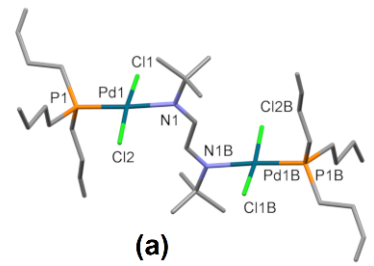

(a)

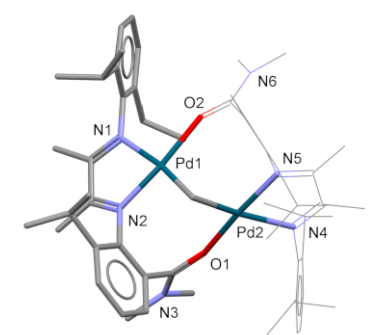

(d)
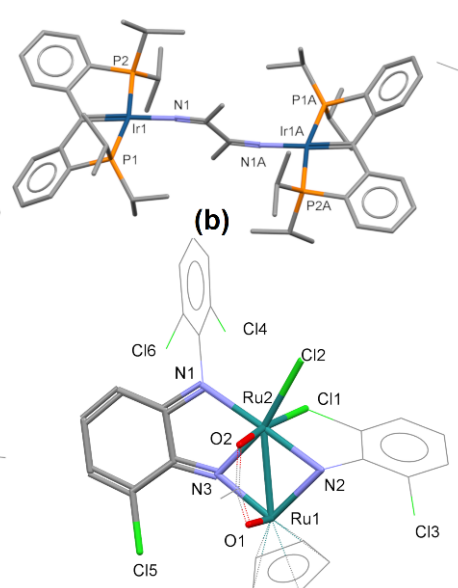

(e)
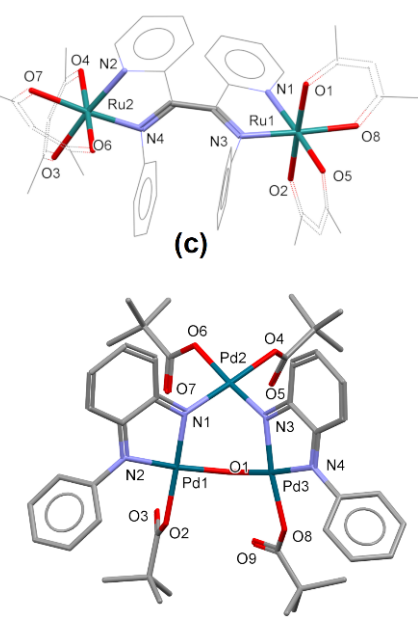

(f)

Figure 5. (a) A mixed homo- and heterobimetallic palladium-platinum complex with the bridging 4e donor $\sigma, \sigma-\mathrm{N}, \mathrm{N}^{\prime}$ coordination mode [132] (CSD Refcode FACKAV); (b) butane-2,3-diiminato ligand synthesized in situ via reductive coupling of acetonitrile at the iridium metallic center [133] (CSD Refcode SEYKOY); (c) unusual synclinal conformation of the bridging 1,2-diimine ligand in the meso-( $\mu$-N, $\mathrm{N}^{\prime}$-diphenyl-1,2-di(pyridin-2-yl)ethane-1,2-diimine)-tetrakis(acetylacetonato)-bi -ruthenium complex [134] (CSD Refcode LOMNIN); (d) bidentate chelating $4 \mathrm{e} \kappa^{2}-\mathrm{N}, \mathrm{N}^{\prime}$ binding mode of $s$-cis diimine moiety in the dipalladium complex [135] (CSD Refcode ADOGEI); (e) tridentate chelating bridging $\mu_{2}-\kappa^{2}: \kappa^{1}$ mode of the coordination of $s$-cis 1,2-diiminebenzene related ligands [136] (CSD Refcode KIGFUD); (f) chelate and bridging ligation by 1,2-diiminebenzene based ligands in potassium bis( $\mu$-N-phenyl-o-phenylenediimiine)-( $\mu$-hydroxo)-tetrakis(pivalato)-tri-palladium(II)xylene solvate dihydrate [137] (CSD Refcode MICDAD). Hydrogen atoms, solvent and counterion molecules were omitted for clarity.

An in situ synthesis of a butane-2,3-diiminato ligand via reductive coupling of acetonitrile at iridium in the presence of phosphine tridentate pincer type PCsp ${ }^{2} \mathrm{P}$ ligand (Figure $5 \mathrm{~b}$; SEYKOY) was reported by Burford et al. [133]. Except of s-trans $\alpha$-diimine ligand the metallic center directly bonds to the carbon atom. Phosphine stabilized palladium complexes are recognized as active catalysts in asymmetric transformations, for example in a tandem cross-coupling $\mathrm{C}-\mathrm{H}$ bond activation reactions [138-140]. However, nitrile reductive coupling at a late transition metal center is unusual.

Khan et al. reported the formation of stable diruthenium complexes of another example of non-innocent 1,2-diimine related ligand but with unusual synclinal and anticlinal conformations with torsions of $78.8(7)$ and $122.9(9)^{\circ}$ along the $\mathrm{N}=\mathrm{C}-\mathrm{C}^{\prime}=\mathrm{N}^{\prime}$ fragment, respectively. These species do not show any oxidative cleavage. The clinal conformation resulted from the presence of four bulky substituents (i.e., two pendant phenyl and two pyridyn-2-yl groups; Figure 5c; LOMNIN) [134]. 
The s-cis conformation of 1,2-diimine in coordination compounds leads to the chelating mode. Zhai et al. studied copolymerization of ethylene with acrylate monomers with the use of functionalized 1,2-diimine. The reported structure of dipalladium complex shows the bidentate chelating $4 \mathrm{e} \kappa^{2}-\mathrm{N}, \mathrm{N}^{\prime}$ binding mode of the diimine moiety (Figure 5d; ADOGEI) [135].

An example of a 1,2-diimine sterically blocked ligand is 1,2-diiminebenzene and its derivatives. The s-cis spatial arrangement of two conjugated imine groups is constrained this time by covalent bonding. Therefore, the ligand may form easily chelates. However, higher nuclearity can be afforded by additional bridging by the imine $\mathrm{N}$ atoms. In the reported structures the tridentate chelating bridging $\mu_{2}-\kappa^{2}: \kappa^{1}$ mode stabilizes diruthenium and tripalladium complexes (Figure 5e,f; KIGFUD and MICDAD) $[136,137]$.

Ghosh et al. reported an interesting method of synthesis of 1,2 diimine ligands by via conversion of benzofuroxan at $\left\{\mathrm{Ru}(\mathrm{acac})_{2}\right\}$, which resulted in heteroatom-carbon formation via oxidation of alcoholic solvent, nucleophilic addition and intermolecular coupling (Figure 6) [141] (YIGHII and YIGHOO).

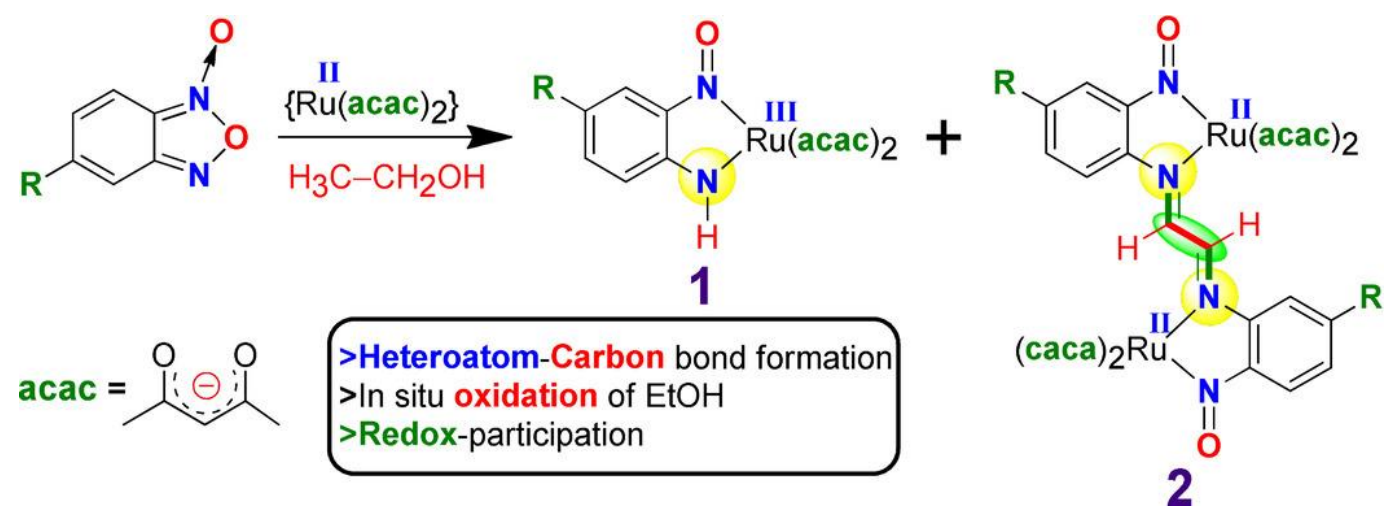

Figure 6. In situ solvent-mediated conversion of benzofuroxan affording 1,2-diimine non-innocent ligand [141]. Reprinted with permission from Ghosh, P.; Dey, S.; Panda, S.; Lahiri, G. K. Solvent-Mediated Functionalization of Benzofuroxan on Electron-Rich Ruthenium Complex Platform. Chem. An Asian J. 2018, 13 (12), 1582-1593. Copyright (2018) John Wiley and Sons.

1,2-Diimine based ligands such as 1,4-diazabutadiene (DAB) have eight electrons prone to coordination. Two lone pairs of imine $\mathrm{N}$ atoms ligating in a $\sigma$-fashion and two pairs of $\pi$ electrons on the $-\mathrm{N}=\mathrm{C}-\mathrm{C}=\mathrm{N}-$ moiety. Therefore, $\mathrm{DAB}$ related molecules are frequently observed to form complexes with platinum group metals in a special way. The scheme of this bonding is as follows. The ligand entity acts as a chelating species to one metal center forming two $\sigma$-bonds, whereas the other metal atom is bonded via two $\eta^{2}-\mathrm{C}=\mathrm{N}$ bonds analogous to pentahapto $\left(\eta^{5}-\right.$ ) bonding mode $\left(8 \mathrm{e} \mu_{2}-\kappa^{2}-\mathrm{N}, \mathrm{N}^{\prime}: \eta^{2}-\mathrm{C}=\mathrm{N}: \eta^{2}-\mathrm{C}^{\prime}=\mathrm{N}^{\prime}\right.$ mode; Scheme $\left.1 \mathrm{j}-\mathrm{m}\right)$. The planar five-membered chelate ring acts like a $\eta^{5}$-cyclopentadienyl analogue.

The examples of such coordination motif may be found both in simple 1,4-diazabutadiene ligands as reported by Abbel et al. (Figure 7a; FIMNAR) [142] as well as in the case of more extended ligands as in the 1,2-diiminobenzene Ru complex, which shows interesting electrochemical properties (Figure $7 \mathrm{~b}$; AROQAZ) [122].

Similar 8e donating $\mu_{2}-\kappa^{2}-\mathrm{N}, \mathrm{N}^{\prime}: \eta^{2}-\mathrm{C}=\mathrm{N}: \eta^{2}-\mathrm{C}^{\prime}=\mathrm{N}^{\prime}$ coordination scheme of DAB ligands are observed for example in oligonuclear metal carbonyl complexes (trinuclear Os [144] (GIRCAL), Ru [143] (CUXFIK), binuclear Ru [145] (GLXRUA10) and tetranuclear Ru [146] (GLXRUB10; Figure 7c-f)).

Keijsper et al. reported an unusual linear $\mathrm{Ru}_{4}$ cluster based on $6 \mathrm{e} \mu_{2}-\kappa^{2}-\mathrm{N}, \mathrm{N}^{\prime}: \eta^{2}-\mathrm{C}^{\prime}=\mathrm{N}^{\prime}$ ligating 1,2-diimine ligand and carbonyl bridges (Figure 7g; DEXBIR) [143].

However, the possible $\eta^{5}$-like coordination mode may be disturbed, and "slipped" complexes are also observed with only one $\eta^{2}-\mathrm{C}=\mathrm{N}$ ligation and rarely encountered three-membered $\mathrm{PdCN}$ ring (Scheme $11, \mathrm{~m}$ ). An example may be a 6e donor $\mu_{2}-\kappa^{2}-\mathrm{N}, \mathrm{N}^{\prime}: \eta^{2}-\mathrm{C}^{\prime}=\mathrm{N}^{\prime}$ coordination mode of DAB ligand, 
which was reported for monohydride metal carbonyl complexes of Ru [147] or described by Owen et al. dipalladium unit with the $\eta^{2}$-coordination mode [148] (Figure 8a,b; WAGKOE, OKAYUU).

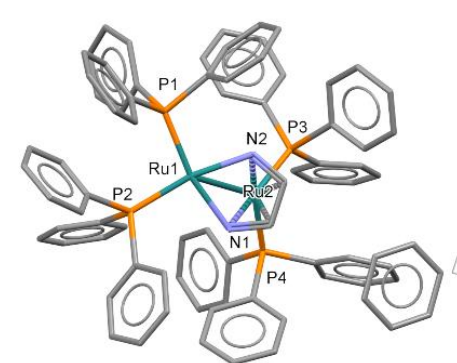

(a)

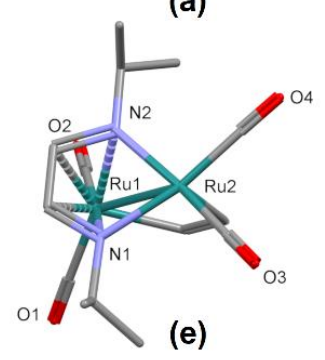

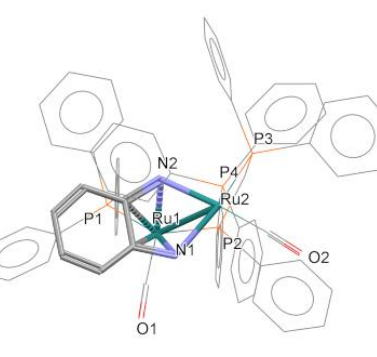

(b)

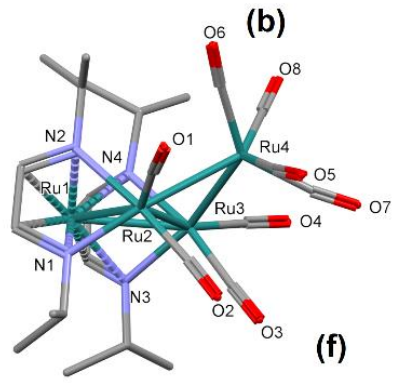

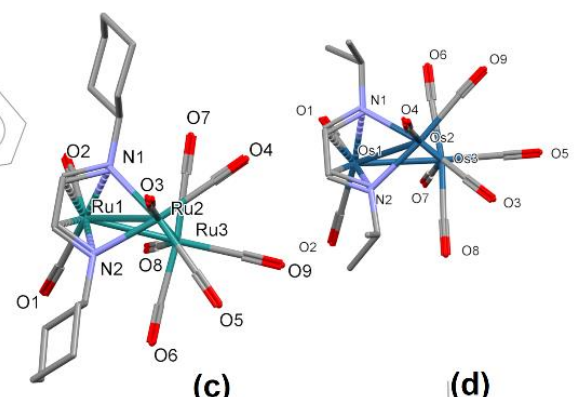

(c)

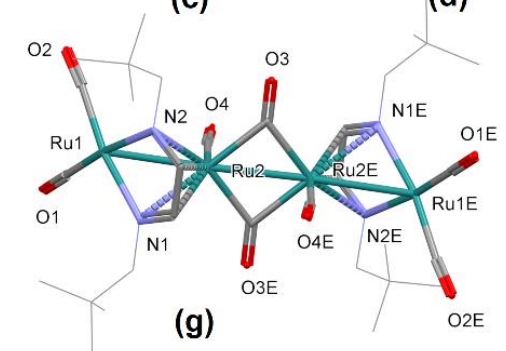

Figure 7. (a) The dual mode of coordination exhibited by 1,4-diazabutadiene ligands in binuclear complexes of with Ru. Chelating ligation and pentahapto-like ( $\eta^{5}-$ ) bonding [142]. (CSD Refcode FIMNAR); (b) cationic part of diruthenium complex with the $\eta^{5}$ coordination mode [122] (CSD Refcode AROQAZ); (c-f) coordination mode $8 \mathrm{e} \mu_{2}-\kappa^{2}-\mathrm{N}, \mathrm{N}^{\prime}: \eta^{2}-\mathrm{C}=\mathrm{N}: \eta^{2}-\mathrm{C}^{\prime}=\mathrm{N}^{\prime}$ of DAB ligands observed in metal carbonyl complexes: CSD Refcodes CUXFIK [143], GIRCAL [144], GLXRUA10 [145] and GLXRUB10 [146] and (g) unusual linear Ru $\mathrm{u}_{4}$ cluster based on the 6e $\mu_{2}-\kappa^{2}-\mathrm{N}_{,} \mathrm{N}^{\prime}: \eta^{2}-\mathrm{C}^{\prime}=\mathrm{N}^{\prime}$ ligating 1,2-diimine ligand [143] (CSD Refcode DEXBIR). Solvent molecules and hydrogen atoms were omitted for clarity.
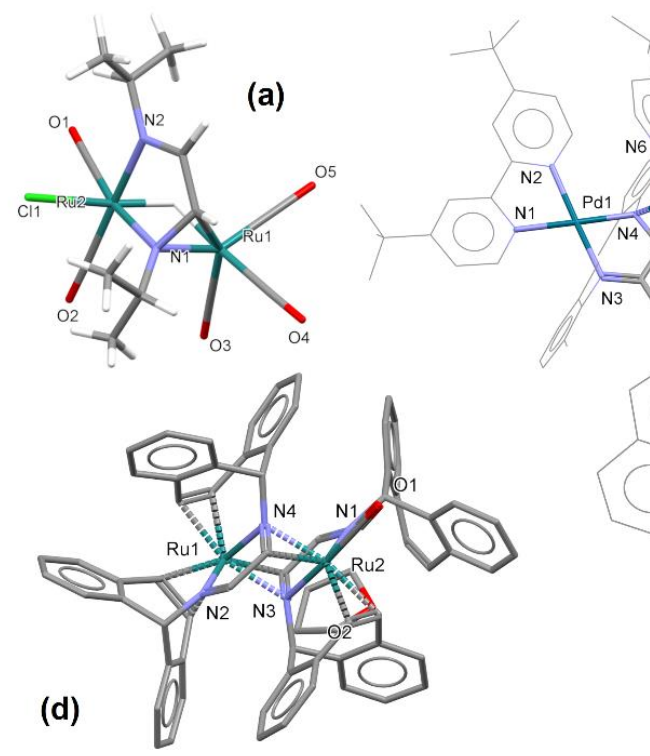

(b)

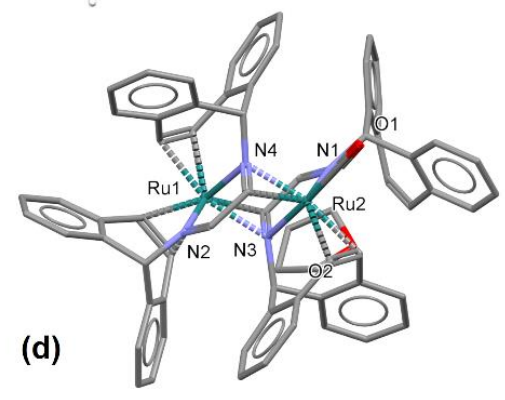

(e)

(e) $\quad \mathrm{Cl}_{\mathrm{S} 1}^{\mathrm{C} 11}$

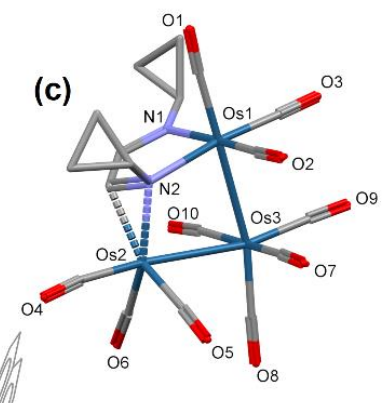

Figure 8. (a) Six electrons donor coordination mode $\left(6 e \mu_{2}-\kappa^{2}-N_{,} N^{\prime}: \eta^{2}-C^{\prime}=N^{\prime}\right)$ of the DAB ligand observed in the monohydride metal carbonyl complex of Ru [147] (CSD Refcode WAGKOE); (b) unusual three-membered PdCN ring with the $\eta^{2}$-coordinated imidoyl group [148] (CSD Refcode OKAYUU); (c) triosmium 6e $\mu_{2}-\kappa^{2}-\mathrm{N}, \mathrm{N}^{\prime}: \eta^{2}-\mathrm{C}^{\prime}=\mathrm{N}^{\prime}$ complex with the DAB related ligand [149] (CSD Refcode GIRDIU); (d) dimeric structure of the complex of the DAB ligand with ruthenium with the coordination mode (6e $\mu_{2}-\kappa^{2}-\mathrm{N}, \mathrm{N}^{\prime}: \eta^{2}-\mathrm{C}^{\prime}=\mathrm{N}^{\prime}$ ) [150] (CSD Refcode YARYEY) and (e) mixed valence tripalladium 6e $\mu_{2}-\kappa^{2}-\mathrm{N}, \mathrm{N}^{\prime}: \eta^{2}-\mathrm{C}^{\prime}=\mathrm{N}^{\prime}$ complex with the non-innocent acenaphthenequinone-based ligand [151] (CSD Refcode XOFZEY). Hydrogen atoms, solvent and counterion molecules were omitted for clarity. 
Zoet et al. described a series of ruthenium carbonyl coordination compounds with the DAB ligand with 4e, 6e and 8e donor coordination modes (Figure 8c; GIRDIU) [149].

The non-innocent DAB ligand was successfully applied in catalytic decarbonylation of aqueous formaldehyde with the production of hydrogen (Figure 8d; YARYEY) [150].

A slipped $6 \mathrm{e} \mu_{2}-\kappa^{2}-\mathrm{N}, \mathrm{N}^{\prime}: \eta^{2}-\mathrm{C}^{\prime}=\mathrm{N}^{\prime}$ bridging was reported by Zhou et al. (Figure 8e; XOFZEY) [151]. This trinuclear complex contained V-shaped palladium cluster stabilized by the bridging non-innocent acenaphthenequinone related ligand. The authors assumed a mixed valence for palladium centers because of the presence of a non-innocent ligand, which may be coordinated as monoanion radical or in the diamagnetic fully reduced dianionic form.

In contrast to 1,2-diimines ( $\alpha$-diketimines), the 1,3-diimines ( $\mathrm{N}^{\prime} \mathrm{N}^{\prime}-\beta$-diketimines) are innocent ligands. However, this class of bidentate ligands can exist as a mixture of tautomers. They may coordinate in a chelating fashion forming six-membered chelate ring. 1,3-Diketimines are often referred to as $\mathrm{HNacNac}$ species. Bourget-Merle et al. reviewed the chemistry of $\beta$-diketiminato metal complexes [152]. The 1,3-diimine derivatives are frequently fused in macrocyclic compounds such as porphyrins or corrins. However, these groups of compounds are behind the scope of this review.

\subsection{Coordination Chelating Pockets Made of Imine Group and Additional Ligating N/O/S Heteroatoms}

The concept of joining the 1,2-diimine fragment with additional ligating $\mathrm{N} / \mathrm{O} / \mathrm{S}$ heteroatoms prone to coordination may lead to coordination chelating pockets (Scheme 2a-d).

The combination with aromatic $\mathrm{N}$ atom may result for example in bidentate chelating $4 \mathrm{e}$ $\kappa^{2}-\mathrm{N}, \mathrm{N}^{\prime}$ mode as in diruthenium complex (AZEQOL) [153] or in a more extended pincer type species (6e $\kappa^{3}-\mathrm{N}, \mathrm{N}^{\prime} \mathrm{N}^{\prime \prime}$ mode, MOTZUT), which may be further used to construct macrocyclic oligonuclear ligands [154] (Figure 9a,b).

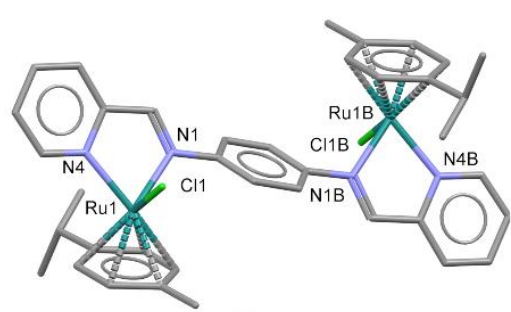

(a)

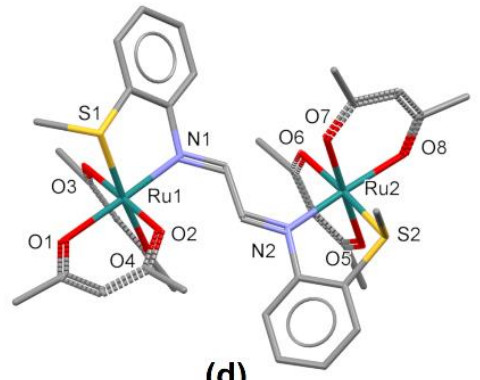

(d)

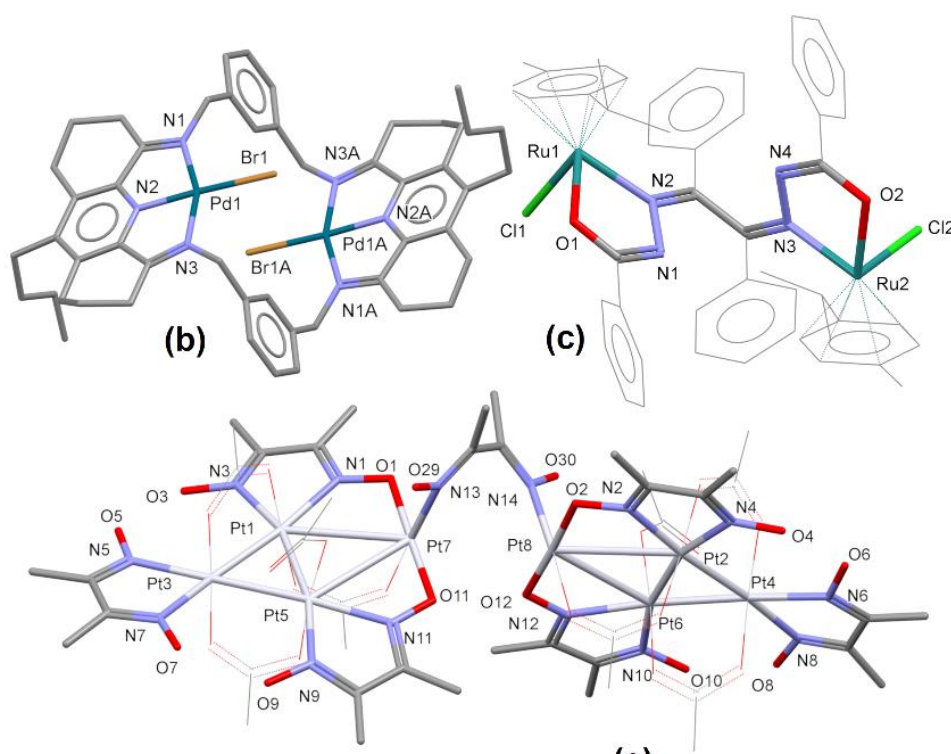

(e)

Figure 9. (a) Diruthenium complex with chelating $\kappa^{2}-\mathrm{N}^{\prime} \mathrm{N}^{\prime}$ pockets [153] (CSD Refcode AZWQOL); (b) cyclic binuclear complex with robust pincer type 6e $\kappa^{3}-\mathrm{N}, \mathrm{N}^{\prime} \mathrm{N}^{\prime \prime}$ coordination mode [154] (CSD Refcode MOTZUT); (c) binuclear complex of ruthenium(II) arene benzil bis(benzoylhydrazone) with coordination chelating $\kappa^{2}-\mathrm{N}, \mathrm{O}$ pockets [155] (CSD Refcode QESSUF); (d) binuclear Ru complex with non-innocent diimine ligand binding through coordination chelating $\kappa^{2}-\mathrm{N}, \mathrm{S}$ pockets [123] (CSD Refcode $\mathrm{KEHSOH}$ ); (e) octaplatinum complex with $\mathrm{Pt}_{3}$ metallic clusters stabilized by bridging and chelating dimethylglyoxime ligand molecules [156] (CSD Refcode MEMLUL). Hydrogen atoms, solvent and counterion molecules were omitted for clarity. 
An example of imine fused with $\mathrm{O}$ ligating atom may be a series of acylhydrazone derivatives forming binucleating template for coordination of $\mathrm{Ru}(\mathrm{II})$ complexes, which were studied on antiproliferative activity and apoptosis induction showing higher cytotoxicity than cis-platin and low IC50 values against the screened cancer HeLa, MDA-MB-231 and Hep-G2 cell lines (Figure 9c; QESSUF) [155]. The presence of additional $\mathrm{O}$ atoms enabled formation of six-membered chelate rings.

An analogous concept was used by Chatterjee et al. who described an in situ formation of a binuclear Ru complex with bridging non-innocent ligand showing interesting electrochemical behavior caused by internal electron transfer (Figure 9d; KEHSOH) [123]. In this case an additional sulphur atom is introduced to give coordination chelating $\kappa^{2}-\mathrm{N}, \mathrm{S}$ pockets.

The modification with heteroatoms may also be applied at imine $\mathrm{N}$ atoms as in dimethylglyoxime, which has the 1,2-diimine fragment and additional oxygen atoms resulting in oxime tetradentate ligand. An octaplatinum complex of dimethylglyoxime was isolated as an intermediate state in the cluster core transformation for stabilization of $\mathrm{Pt}_{3}$ metallic clusters (Figure 9e; MEMLUL) [156]. However, this type of imine ligand modification together with various pincer type pockets is out of the scope of this review.

\subsection{Oligonuclear Complexes Based on $\mathrm{N}_{2} \mathrm{O}_{2}$ Compartmental SB Ligands}

\subsubsection{Classic bi- or Trinuclear Systems, which are $\mathrm{N}_{2} \mathrm{O}_{2}$-compartmental Schiff Bases}

The $\mathrm{N}_{2} \mathrm{O}_{2}$-compartmental Schiff base (Scheme 2e,f) are intensively used for studying of various transition metal complexes, however, there are only two structural reports on a series of crystal structures of classic heterobi- and heterotrinuclear systems in which the platinum group metals (Pt or Pd) were coordinated inside the $\mathrm{N}_{2} \mathrm{O}_{2}$-compartmental Schiff bases coordination site (Figure 10a,b; DEMPUJ and DIPDAK) [44,157].

These structures proved the flexibility of selected bi-compartmental $\mathrm{N}_{2} \mathrm{O}_{2}-\mathrm{O}_{2} \mathrm{O}_{2}^{\prime}$ Schiff base skeletons to accommodate simultaneously the $\mathrm{Pd}(\mathrm{II})$ or $\mathrm{Pt}(\mathrm{II})$ ions (which demand a special planar tetragonal coordination environment) in the inner $\mathrm{N}_{2} \mathrm{O}_{2}$ pocket and lanthanide ions in the outer $\mathrm{O}_{2} \mathrm{O}_{2}^{\prime}$ binding site. In case of heterotrinuclear $\mathrm{Pd}(\mathrm{II})-4 \mathrm{f}$ metal complexes the appropriate geometry for the auxiliary lanthanide ion was achieved by a propeller like arrangement of two Schiff base ligands resulting in linear trinuclear complexes that was previously observed for classic nonPGM homonuclear $3 \mathrm{~d}$ or heteronuclear $3 \mathrm{~d}-4 \mathrm{f}$ species enabling via bridges intermetallic interactions [162-166].

\subsubsection{Strategy of Addition of Auxiliary Bridging Ligands}

To increase the nuclearity of mono- or binuclear units the strategy of addition of auxiliary bridging ligands was developed. In this approach the metal centers of mono-, bi- or oligonuclear complexes with $\mathrm{N}_{2} \mathrm{O}_{2}$ compartment Schiff bases may be bridged via various molecules or ions. For this application the following species were applied oxo, pyrazino, diphosphinidino and 1,1'-ferrocenediphosphiniminato [167] and even dinitrogen [158].

Man et al. studied the catalytic reduction of $\mathrm{N}_{2}$ and discovered that $\mathrm{N} \cdots \mathrm{N}$ coupling proceeds at room temperature in the presence of a SB ligand to provide a $\mu$-dinitrogen complex (Figure 10c; MAHDAC) [158].

The auxiliary cyanide anions are frequently used in heteroleptic polymer systems bridging the metallic centers [168]. However, there are also known oligonuclear PGM species giving opportunity to intermetallic exchange interactions and resulting for example in single-molecule magnet properties [159,160,169-171].

Ru et al. reported the most recent examples of cyano-bridged heterobimetallic PGM compounds [159], in which the ferromagnetic coupling between metallic centers of $\mathrm{Ru}^{\mathrm{III}}$ and $\mathrm{Ni}^{\mathrm{II}}$ were enabled through the cyanide bridges (Figure 10d; KILRIJ).

The cyanide bridges were applied to study the phenomenon of switching off the single-molecule magnet upon complexation of mononuclear $\mathrm{Co}(\mathrm{II})$ coordination unit with salen $\mathrm{Ru}(\mathrm{III})$ system (Figure 10e; BODHEJ) [160]. 


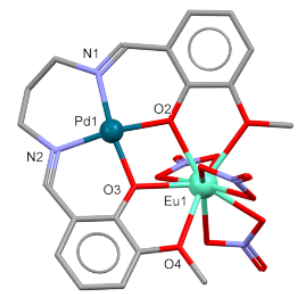

(a)

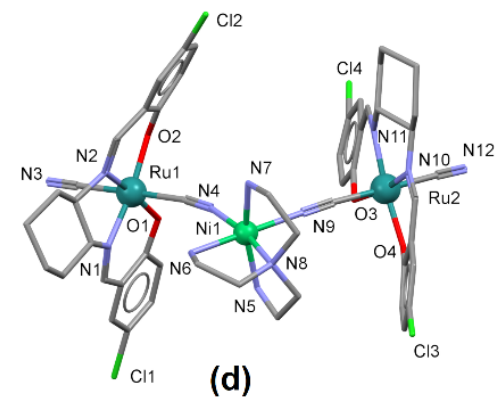

(d)

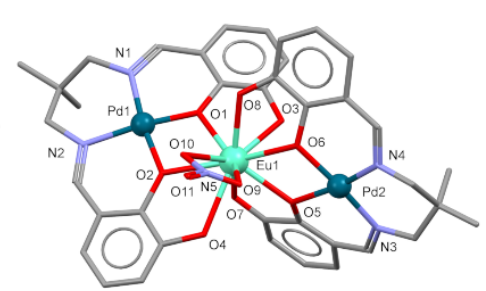

(b)

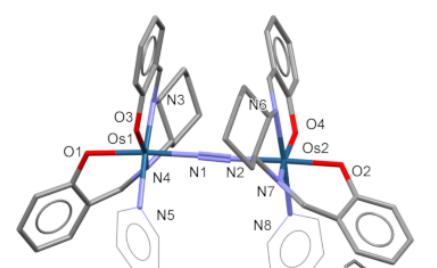

(c)

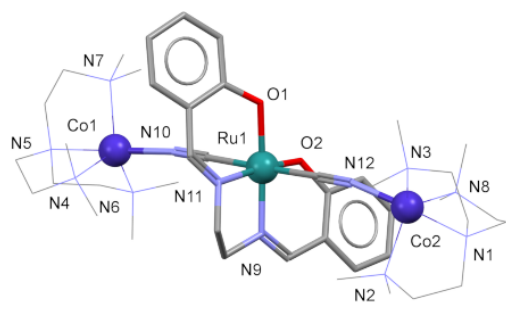

(e)

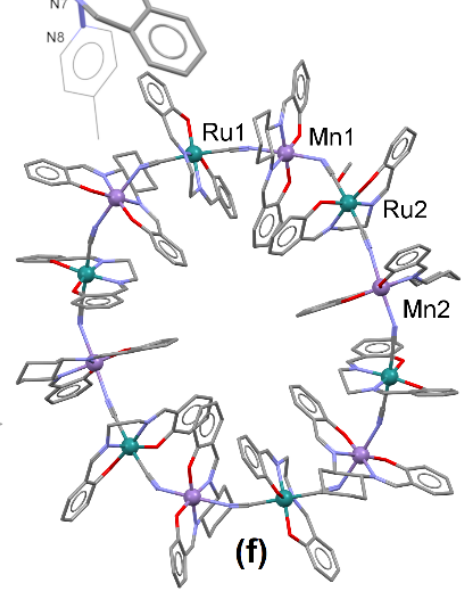

Figure 10. (a) Heterobinuclear Pd-Eu complex with bi-compartmental $\mathrm{N}_{2} \mathrm{O}_{2}-\mathrm{O}_{2} \mathrm{O}_{2}^{\prime}$ Schiff base ligand [157] (CSD Refcode DEMPUJ); (b) heterotrinuclear Pd-Eu-Pd coordination compound with propeller like arrangement of two Schiff base ligands [44] (CSD Refcode DIPDAK); (c) diosmium $\mu$-dinitrogen complex [158] (CSD Refcode MAHDAC); (d) heterobimetallic trinuclear cyano-bridged complex of bis( $\mu$-cyanido)-dicyanido-bis(2,2'-[(R,R) -cyclohexane-1,2-diylbis(azanylylidenemethylylidene)]bis(4-chlorophenolato))-(tris(2-aminoethyl)amine) -nickel(II)-bi-ruthenium(III) [159] (CSD Refcode KILRIJ); (e) trinuclear Co-Ru-Co cyanido-bridged complex [160] (CSD Refcode BODHEJ); (f) dodecanuclear macrocyclic cyanido-bridged 3d-4d heterobimetallic complex [161] (CSD Refcode VIVCOV). Solvent molecules and hydrogen atoms were omitted for clarity.

\subsubsection{Nano-sized Magnetic Molecular Wheel}

Cyanide anions bridging homo- or heterometallic systems may afford bi-, oligo- up to polymeric coordination structures [168]. However, Zhang et al. reported spectacular dodecanuclear macrocyclic cyanido-bridged $4 \mathrm{~d}-3 \mathrm{~d}$ heterobimetallic complexes. The complexes were synthesized via reaction performed at room temperature starting form precursors in the form of appropriate mononuclear Schiff-base complexes. It is an example of a chiral magnetic molecular wheel exhibiting the single molecular magnet (SMM) behavior (Figure 10f; VIVCOV) [161].

\subsubsection{Hybrid Materials Made of $\mathrm{N}_{2} \mathrm{O}_{2}$ Coordination Sites as Building Block}

An interesting approach to oligonuclear complexes of fixed number of ligated metal centers is the application of fused ligands. The $\mathrm{N}_{2} \mathrm{O}_{2}$ compartment SB ligands exhibit excellent coordination properties. The combination of covalently bonded SB subunits by a "fusing agent" may give new ligands of higher number of coordination sites, both cyclic and acyclic (Scheme 2g-i). The geometry and coordination mode depend on the structure of the covalently bonded linker. Ligands fused by a stiff "fusing agent" frequently are flat, which favors intermolecular interactions in the form of stacking and intermetallic contacts providing additional tool in crystal engineering to stabilize the supramolecular structure. In the case of flexible "fusing agents" the molecule can change its conformation and adapt the shape to the guest molecules for example in molecular tweezers or helical structures. Finally, if the "covalent fusing" results in cyclic macromolecules, the conformation of the oligodentate ligand depends again on the shape adaptability of the molecular linkers giving opportunity to construct interlocked structures such as macrocycles, cages or molecular knots [172].

Houjou et al. presented a series of complexes of group 10 metal ions with ligands built of two $\mathrm{N}_{2} \mathrm{O}_{2}$ compartment SB subunits together with their luminescent properties [41]. The binuclear species interacted with each other via stacking and metallophilic interactions with the Pt-Pt distance of 3.434 A (Figure 11a; GEDBEZ). 


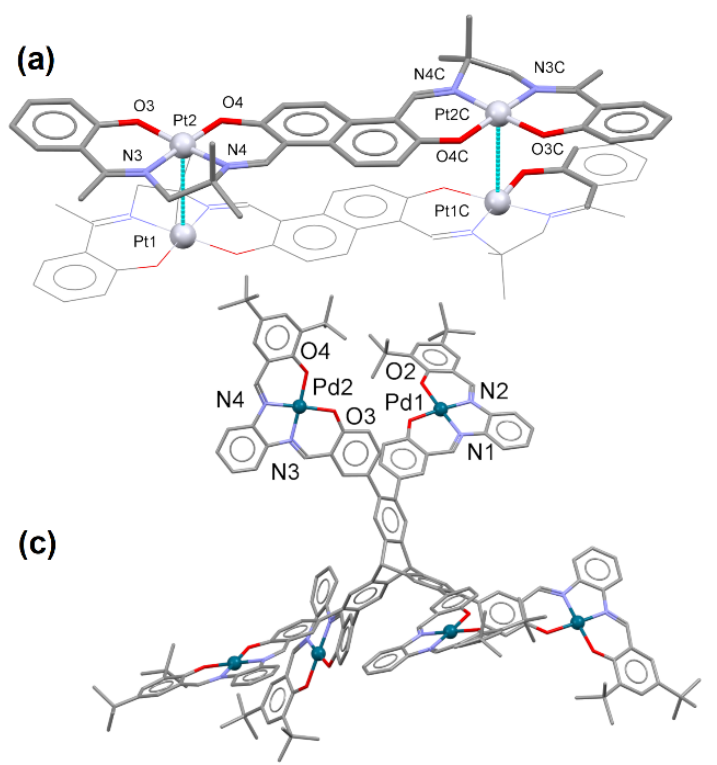

(b)

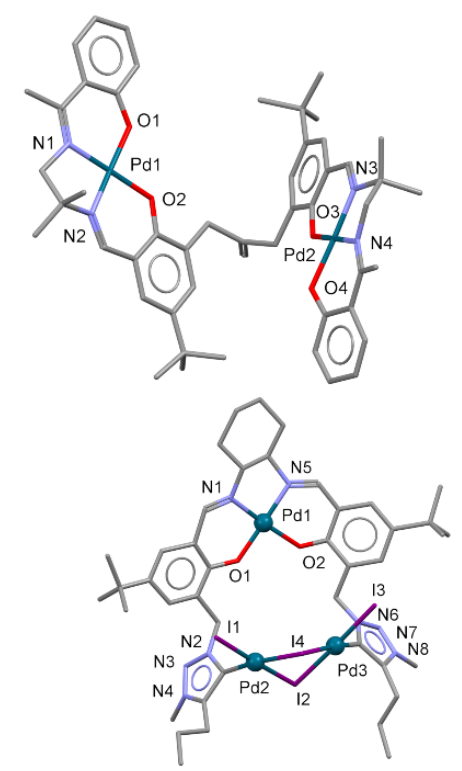

Figure 11. (a) Platinum(II) complex based on fused $\mathrm{N}_{2} \mathrm{O}_{2}$ Schiff base ligand and metallophilic interactions [41]. (CSD Refcode GEDBEZ); (b) binuclear coordination compound of palladium exhibiting mechanochromic photoluminescent properties [42] (CSD Refcode UMAWUC); (c) hexanuclear palladium triptycene based hexakis(metalsalphen) coordination compound [173] (CSD Refcode MIRSEO) and (d) trinuclear salen-mesoionic N-heterocyclic carbene hybrid complex of $\mathrm{Pd}$ (II) one of the symmetrically independent molecules [174] (CSD Refcode SELCIY). Solvent molecules and hydrogen atoms were omitted for clarity.

Simple heterobinuclear coordination compounds of Pd and Pt showed unusual mechanochromic photoluminescent properties making them attractive candidates as functional materials in memory devices (Figure 11b; UMAVUC) [42].

Reinhard et al. reported the synthesis and characterization of metal-assisted salphen organic framework (MaSOF) based on triptycenehexakissalicylaldehyde (Figure 11c; MIRSEO) [173]. To obtain microporous oligonuclear materials they used a template of triptycene moiety as a molecular skeleton base modified with the presence of $\mathrm{N}_{2} \mathrm{O}_{2}$ salphen type coordination pockets. The complexes were studied for the application as organic molecules of intrinsic microporosity (OMIM) materials. Such oligonuclear compounds have advantage over polymeric structures in application for gas sorption to be more soluble and defectless materials.

Schmid et al. applied the strategy of fusion of SB ligands with other type of functional materials for synthesis of oligonuclear salen-mesoionic N-heterocyclic carbene hybrids (Figure 11d; SELCIY) [174]. These compounds were studied on catalytic activity in the 1,4-addition of an oxindole to a nitroolefin.

\subsection{Cyclic and Acyclic Macromolecules Made of Fused Schiff Base Units Resulting in Oligodentate Ligands}

\subsubsection{Macrocycles}

Another approach is the synthesis of macrocyclic species [175]. The $\mathrm{N}_{2} \mathrm{O}_{2}$-based coordination pocket is an efficient building block for metallohost structures. For example, Robson-type macrocyclic complexes may be derived from condensation of achiral diamines and 2-hydroxy -5-methyl-benzene-1,3-dicarbaldehyde. Analogous to calixarene Li and Jablonski introduced a term of "calixsalen" in case of Schiff base macrocycles [176]. Many interesting ligand structures [177,178] and examples of PGM heterooligonuclear species (Figure 12a; MIKQIJ) were reported in the following papers $[45,179,180]$. In the case of PGM this approach for obtaining of homo- and heterooligonuclear species is particularly important, as these metals do not form oligonuclear complexes as easily as other metals. 

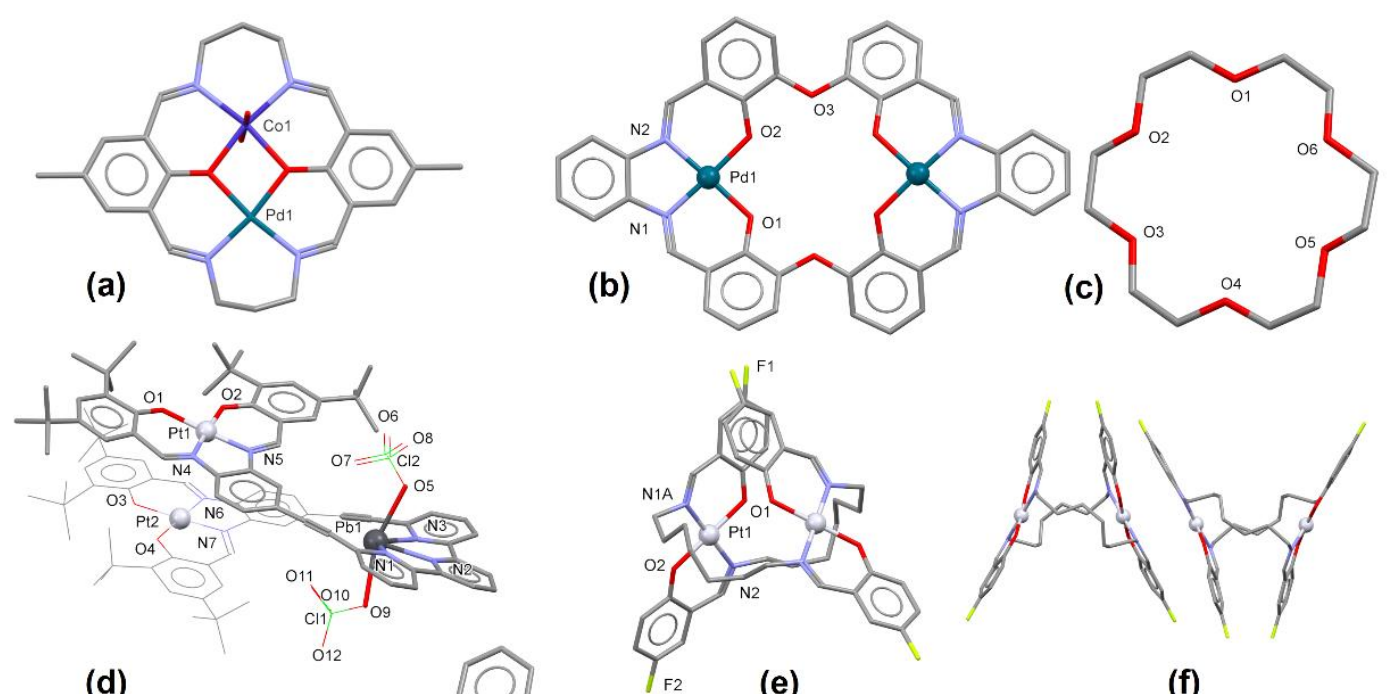

(d)
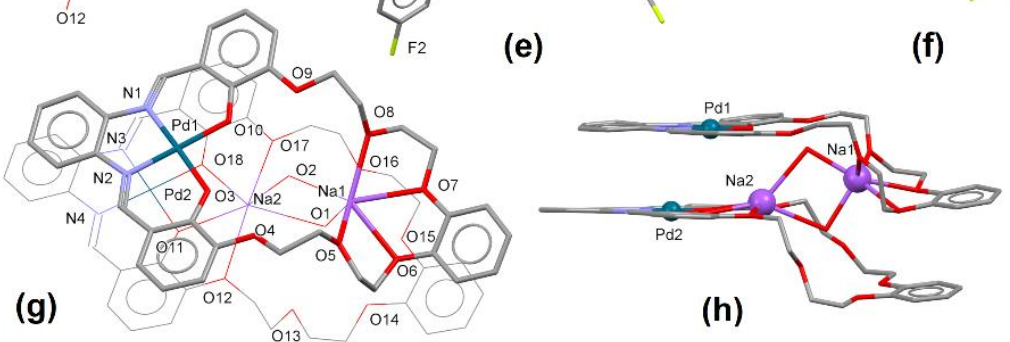

Figure 12. (a) A simple example of binuclear coordination compound based on calixsalen-Schiff base macrocycle [45] (CSD Refcode MIKQIJ); (b) 18-Crown-6-like binuclear metallohost based on two Pd metallosalen fragments [181] (CSD Refcode FARNIY); (c) macrocyclic 18-Crown-6 polyether [182] (CSD Refcode ABULOZ); (d) molecular tweezers based on Pt-salphen-terpyridine moiety for selective recognition of divalent cations helically closed on recognition of the $\mathrm{Pb}^{2+}$ ion [183] (CSD Refcode BORCES); (e) one of the symmetrically independent molecules and (f) side view at molecules of bis $(\mu$ -2,2'-\{heptane-1,7-diylbis[azanylylidenemethanylylidene]\}bis(4-fluorophenolato))-bi-platinum [184] (CSD Refcode YOLDEL) and (g) dimeric tetranuclear complexes of palladium(II) and alkali metal(I) ions based on crown ether-macrocycle with salophen related metallohost (h) and a side view [185] (CSD Refcode AYOYOC). Hydrogen atoms, solvent and counterion molecules were omitted for clarity.

Macrocyclic species may be extended into oligodentate metallohosts, which may be utilized for the recognition of alkali or alkaline earth metal ions such as crown compounds (Figure 12b,c; FARNIY and ABULOZ) [181,182].

The calixsalen molecules named analogous to calixarene were documented to self-assemble into larger species [186]. Akine and Nabeshima published an excellent review on cyclic and acyclic oligo $\left(\mathrm{N}_{2} \mathrm{O}_{2}\right)$ ligands, however, they focused on the ligand's structure and not on a particular group of metals [175].

\subsubsection{Metallohelical Structures}

Doistau et al. reported on application of salphen related switchable molecular tweezers for selective recognition of divalent cations. The ligand is built of the terpyridine central part supplemented by two Pt-salphen pockets (Figure 12d; BORCES) [43,183]. A similar structure was synthesized based on the 4,5-dibromo-9,9-dimethyl-9H-xanthene precursor [187].

Cyclic binuclear clothespin shaped complexes of trans-bis(salicylaldiminato)platinum(II) and trans-bis( $\beta$-iminoaryloxy)palladium(II) were synthesized by Ikeshita et al. (Figure 12e,f; YOLDEL) [184] and Naito et al. [188,189].

Yoon et al. reported on interesting crown ether-macrocycle with incorporated building blocks of salophen moiety [185]. They succeeded in synthesis of dimeric tetranuclear complexes of palladium(II) and alkali metal(I) ions (Figure 12g,h; AYOYOC). 


\subsubsection{Tweezers}

Supramolecular recognition is another approach, which may increase the nuclearity of complexes. A host-guest adduct of a tweezer type dipalladium and a neutral platinum species was synthesized. The structure is stabilized by stacking interactions and intermetallic contacts between $\mathrm{Pd}$ and $\mathrm{Pt}$ atoms (Figure 13a; JAJWIB) [190].
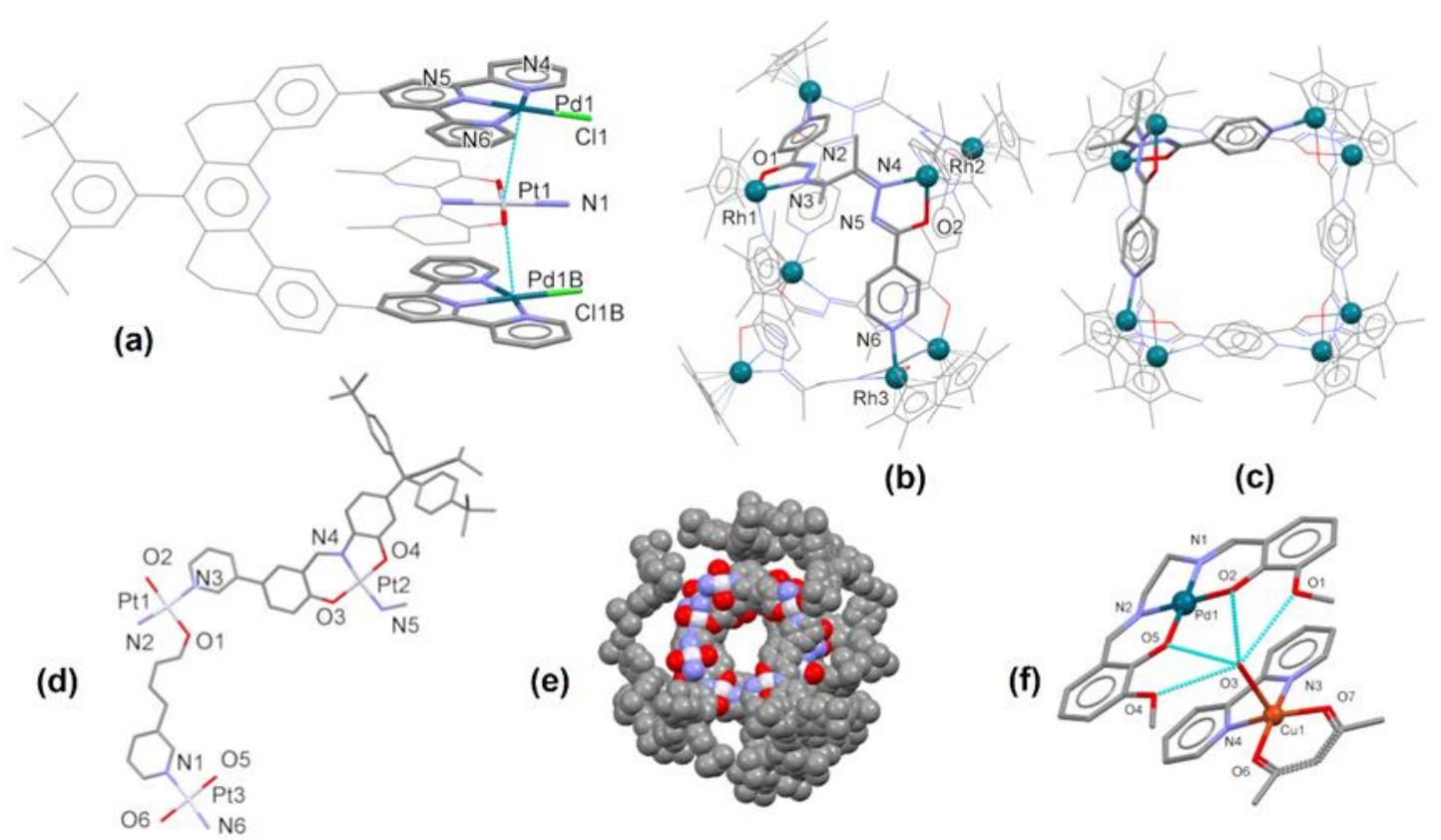

(b)

(c)

(e)

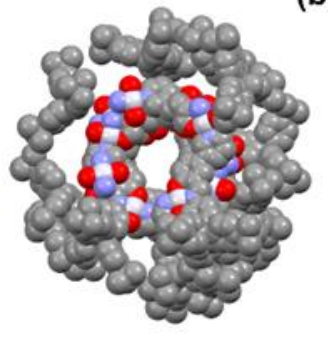

(f)

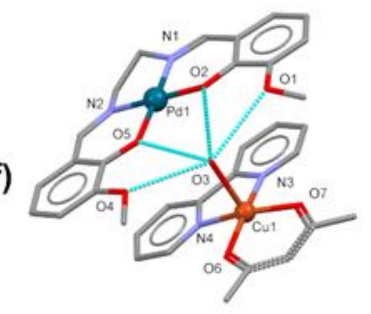

Figure 13. (a) Intermetallic contacts between $\mathrm{Pd}$ and $\mathrm{Pt}$ atoms in a host-guest adduct of a tweezer type dipalladium complex and a neutral platinum species [190] (CSD Refcode JAJWIB); (b) half sandwich $\mathrm{M}_{8}(\mathrm{~L})_{4}$ cubic cage of rhodium ( $\mathrm{L}=2$,3-butanedione bis(isonicotinyl hydrazine)) (c) and a side view [191] (CSD Refcode UROREA); (d) one of oligonuclear Pt coordination units (e) and a view at nanotubular macrocycle aggregate presented as van der Waals spheres [192] (CSD Refcode BEHVUH) and (f) supercomplex built of square planar coordination entities acting as host receptors for aqua ligands coordinated by another coordination unit [193] (CSD Refcode TEGBUD). Hydrogen atoms, solvent and counterion molecules were omitted for clarity.

\subsubsection{Cages}

Coordination cages are molecular self-assembly [194-196]. Liu et al. synthesized and characterized a series of half-sandwich polyhedral cages based on flexible SB ligands. For example 2,3-butanedione bis(isonicotinyl hydrazine) was used for synthesis of the octanuclear rhodium cubic cage (Figure 13b,c; UROREA) [191].

\subsection{Cocrystals}

Frischmann et al. presented a template-free approach for constructing nanotubular aggregates of macrocycles stabilized by stacking interactions [192]. They succeeded in the synthesis of molecular materials with substantial porosity based on discrete $\mathrm{Pt}_{4}$ macrocycle aggregates (Figure 13d,e; $\mathrm{BEHVUH}$ ).

Bicompartment $\mathrm{N}_{2} \mathrm{O}_{2}-\mathrm{O}_{2} \mathrm{O}_{2}^{\prime}$ SBs were an object for studying of supercomplexes and a construction of a second coordination sphere [193]. The square planar coordination entities act as host receptors for aqua ligands coordinated by another coordination unit (Figure 13f; TEGBUD). Such cocrystallization gives new opportunities in coordination chemistry. 


\subsection{Metallophilic Interactions in Oligonuclear Species}

Krisyuk et al. studied an interesting concept of utilization of metallophilic interactions to extend oligonuclear structures to higher order species up to coordination polymers basing on a series of $\mathrm{Pd}-\mathrm{Pb}$ complexes. Dimers combined via metallophilic interactions formed tetramers or coordination polymers (Figure 14a,b; HIJXEF, HIJWUU). As the strength of metallophilic interactions is of order of hydrogen bonding's, such new entities may result in interesting physicochemical properties [197].
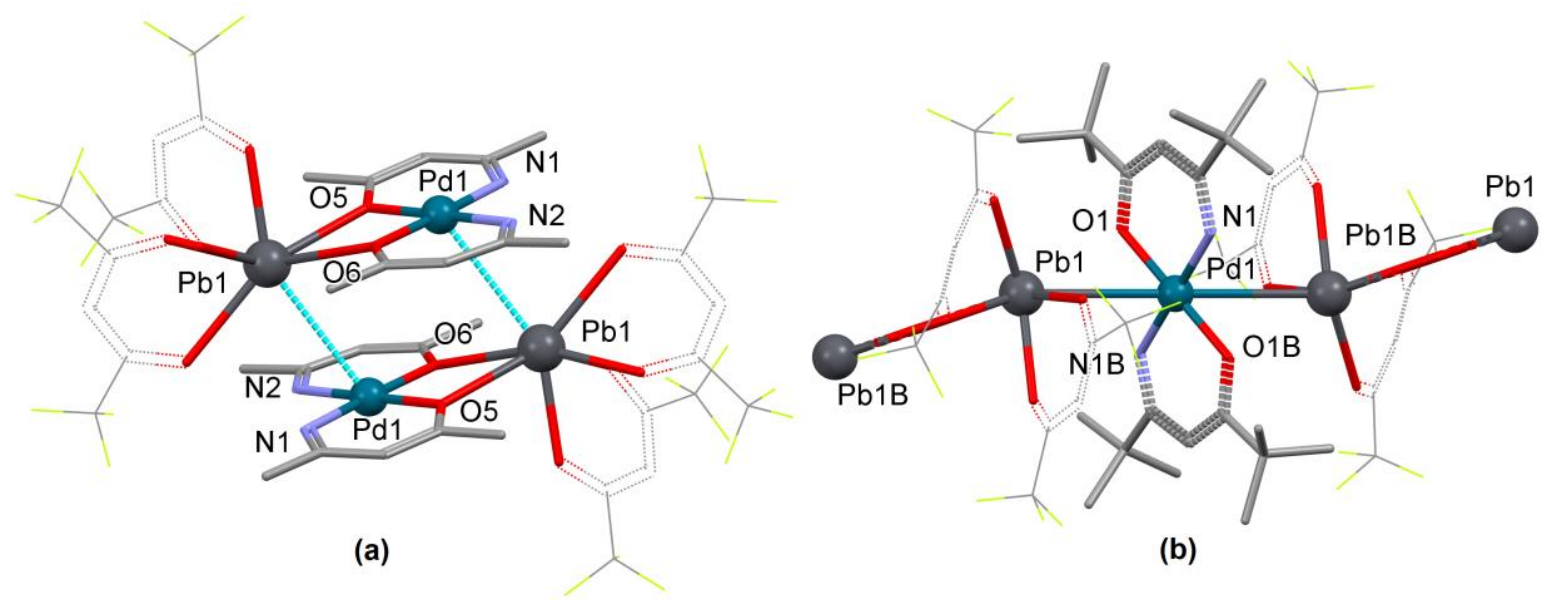

(b)

Figure 14. (a) Tetrameric (CSD Refcode HIJXEF) (b) and polymeric (CSD Refcode HIJWUU) structures based on metallophilic interactions with Pd-Pb distances of 3.551 and $3.459 \AA$, respectively [197].

\section{Materials and Methods}

\section{Methods of Database Analysis}

The Cambridge Structural Database (CSD, version 5.41, update March 2020) [198] was used to extract the most recent achievements in the field of homo- and hetero- bi- and oligonuclear coordination compounds of platinum group metals (PGM) ligated by the imine group. The searches were carried out to retrieve complexes with at least two metallic centers in the coordination entity and with at least one metal belonging to PGM group, where PGM $=\mathrm{Ru}, \mathrm{Rh}, \mathrm{Pd}, \mathrm{Os}$, Ir or Pt coordinated by the imine group. The results were classified into distinct categories as presented in Schemes 1 and 2 and described in the manuscript. The database CSD Refcodes are given in the text of the manuscript next to the description of a particular crystal structure to provide reader with a quick reference. The author made an attempt to choose the most recent and most characteristic examples to present them to the reader. However, the author regrets not to include many other interesting studies due to a limited scope of this review. The molecular structures and schemes of coordination modes were visualized using Mercury 4.0 [199] and Chemsketch [200], respectively.

\section{Conclusions}

The aim of this review was to present the most significant concepts and strategies of construction and possible applications of the less studied but nevertheless important oligonuclear SB complexes of platinum group metals.

Oligonuclear imine platinum group metals (PGMs) complexes may be a promising platform for energy materials, especially in recently developing dye-sensitized solar cells (DSSCs) as well as in thermoelectric applications. The other field of emerging applications is gas storage materials based on organic molecules of intrinsic microporosity (OMIM) instead of polymers. Oligonuclear PGM complexes may find application as phosphorescent emitters in organic light-emitting diodes (OLEDs) because of existing metallophilic interactions in clusters. Oligonuclear complexes may also contribute to development of efficient optical or electrochemical sensors. The integration of Schiff base 
ligands and platinum group metals gives versatile possibilities of catalytic activity. Cyano-bridged structures may switch on/switch-off the single molecule magnet behavior. The oligonuclear entities have an advantage over the mononuclear or polynuclear species exhibiting usually better physicochemical properties than mononuclear ones and having higher solubility than polymers.

The future research directions in SB-PGM coordination chemistry in general should take into account the interplay between various weaker driving forces and additional more subtle interactions such as stacking or metallophilic interactions, which may result in novel useful oligonuclear materials.

Author Contributions: Conceptualization, methodology, writing-review and editing B.M. All authors have read and agreed to the published version of the manuscript.

Funding: This research received no external funding.

Acknowledgments: I kindly thank Luca Rigamonti for the invitation to participate in this special issue on Oligonuclear Metal Complexes with Schiff Base Ligands. The permissions to use the published materials were kindly granted by American Chemical Society and John Wiley and Sons.

Conflicts of Interest: The authors declare no conflict of interest.

\section{References}

1. Schiff, H. Mittheilungen aus dem Universitätslaboratorium in Pisa: Eine neue Reihe organischer Basen. Justus Liebigs Ann. Der Chem. 1864, 131, 118-119. [CrossRef]

2. Lewiński, J.; Prochowicz, D. Assemblies Based on Schiff Base Chemistry. In Comprehensive Supramolecular Chemistry II; Elsevier: Amsterdam, The Netherlands, 2017; pp. 279-304. ISBN 9780128031995.

3. Whiteoak, C.J.; Salassa, G.; Kleij, A.W. Recent advances with $\pi$-conjugated salen systems. Chem. Soc. Rev. 2012, 41, 622-631. [CrossRef]

4. Kleij, A.W. Zinc-centred salen complexes: Versatile and accessible supramolecular building motifs. J. Chem. Soc. Dalt. Trans. 2009, 24, 4635-4639. [CrossRef]

5. Tidwell, T.T. Hugo (Ugo) Schiff, Schiff bases, and a century of $\beta$-lactam synthesis. Angew. Chem. Int. Ed. 2008, 47, 1016-1020. [CrossRef]

6. Qin, W.; Long, S.; Panunzio, M.; Biondi, S. Schiff bases: A short survey on an evergreen chemistry tool. Molecules 2013, 18, 12264-12289. [CrossRef]

7. Layer, R.W. The chemistry of imines. Chem. Rev. 1963, 63, 489-510. [CrossRef]

8. Vigato, P.A.; Tamburini, S. The challenge of cyclic and acyclic schiff bases and related derivatives. Coord. Chem. Rev. 2004, 248, 1717-2128. [CrossRef]

9. Vigato, P.A.; Tamburini, S.; Bertolo, L. The development of compartmental macrocyclic Schiff bases and related polyamine derivatives. Coord. Chem. Rev. 2007, 251, 1311-1492. [CrossRef]

10. Aguiari, A.; Bullita, E.; Casellato, U.; Guerriero, P.; Tamburini, S.; Vigato, P.A. Macrocyclic and macroacyclic compartmental Schiff bases: Synthesis, characterization, $\mathrm{X}$-ray structure and interaction with metal ions. Inorg. Chim. Acta 1992, 202, 157-171. [CrossRef]

11. Garnovskii, A.D.; Sadimenko, A.P.; Vasilchenko, I.S.; Garnovskii, D.A.; Sennikova, E.V.; Minkin, V.I. Chapter 5 Hetarylazomethine Metal Complexes. Adv. Heterocycl. Chem. 2009, 97, 291-392.

12. Liu, X.; Manzur, C.; Novoa, N.; Celedón, S.; Carrillo, D.; Hamon, J.-R.R. Multidentate Unsymmetrically -Substituted Schiff bases and Their Metal Complexes: Synthesis, Functional Materials Properties, and Applications to Catalysis. Coord. Chem. Rev. 2018, 357, 144-172. [CrossRef]

13. Liu, X.; Hamon, J.-R. Recent developments in penta-, hexa- and heptadentate Schiff base ligands and their metal complexes. Coord. Chem. Rev. 2019, 389, 94-118. [CrossRef]

14. Al Zoubi, W.; Al-Hamdani, A.A.S.; Ko, Y.G. Schiff bases and their complexes: Recent progress in thermal analysis. Sep. Sci. Technol. 2017, 52, 1052-1069. [CrossRef]

15. Rezaeivala, M.; Keypour, H. Schiff base and non-Schiff base macrocyclic ligands and complexes incorporating the pyridine moiety-The first 50 years. Coord. Chem. Rev. 2014, 280, 203-253. [CrossRef]

16. Gavey, E.L.; Pilkington, M. Coordination complexes of 15-membered pentadentate aza, oxoaza and thiaaza Schiff base macrocycles "Old Complexes Offer New Attractions". Coord. Chem. Rev. 2015, 296, 125-152. [CrossRef] 
17. Radecka-Paryzek, W. Self-assembly in schiff base lanthanide complexes-From supramolecular dimers to coordination polymers. Can. J. Chem. 2009, 87, 1-7. [CrossRef]

18. Yang, Z.; Sun, P. Compare of three ways of synthesis of simple Schiff base. Molbank 2006, 6, M514. [CrossRef]

19. Segura, J.L.; Mancheño, M.J.; Zamora, F. Covalent organic frameworks based on Schiff-base chemistry: Synthesis, properties and potential applications. Chem. Soc. Rev. 2016, 45, 5635-5671. [CrossRef]

20. Cordes, E.H.; Jencks, W.P. On the Mechanism of Schiff Base Formation and Hydrolysis. J. Am. Chem. Soc. 1962, 84, 832-837. [CrossRef]

21. Taguchi, K.; Westheimer, F.H. Catalysis by Molecular Sieves in the Preparation of Ketimines and Enamines1. J. Org. Chem. 1971, 36, 1570-1572.

22. Naeimi, H.; Sharghi, H.; Salimi, F.; Rabiei, K. Facile and efficient method for preparation of Schiff bases catalyzed by $\mathrm{P}_{2} \mathrm{O}_{5} / \mathrm{SiO}_{2}$ under free Solvent conditions. Heteroat. Chem. 2008, 19, 43-47. [CrossRef]

23. Chakraborti, A.K.; Bhagat, S.; Rudrawar, S. Magnesium perchlorate as an efficient catalyst for the synthesis of imines and phenylhydrazones. Tetrahedron Lett. 2004, 45, 7641-7644. [CrossRef]

24. White, W.A.; Weingarten, H. A Versatile New Enamine Synthesis. J. Org. Chem. 1967, 32, 213-214. [CrossRef]

25. Gogoi, P.; Gogoi, S.R.; Devi, N.; Barman, P. Aluminium chloride-catalyzed synthesis of 4-benzyl cinnolines from aryl hydrazones. Synth. Commun. 2014, 44, 1142-1148. [CrossRef]

26. Billman, J.H.; Tai, K.M. Reduction of Schiff Bases. II. Benzhydrylamines and Structurally Related Compounds. J. Org. Chem. 1958, 23, 535-539. [CrossRef]

27. Tanaka, K.; Shiraishi, R. Clean and efficient condensation reactions of aldehydes and amines in a water suspension medium. Green Chem. 2000, 2, 272-273. [CrossRef]

28. Bekdemir, Y.; Efil, K. Microwave Assisted Solvent-Free Synthesis of Some Imine Derivatives. Org. Chem. Int. 2014, 2014, 1-5. [CrossRef]

29. Varma, R.S.; Dahiya, R.; Kumar, S. Clay catalyzed synthesis of imines and enamines under solvent-free conditions using microwave irradiation. Tetrahedron Lett. 1997, 38, 2039-2042. [CrossRef]

30. Zolfigol, M.A.; Tavasoli, M.; Moosavi-Zare, A.R.; Arghavani-Hadi, P.; Zare, A.; Khakyzadeh, V. Solvent-free synthesis of N-sulfonyl imines using WCl6 as a novel, highly efficient and reusable catalyst. RSC Adv. 2013, 3, 7692-7696. [CrossRef]

31. Texier-Boullet, F. A Simple, Convenient and Mild Synthesis of Imines on Alumina Surface without Solvent. Synthesis (Stuttg.) 1985, 1985, 679-681. [CrossRef]

32. Rao, V.K.; Reddy, S.S.; Krishna, B.S.; Naidu, K.R.M.; Raju, C.N.; Ghosh, S.K. Synthesis of schiff's bases in aqueous medium: A green alternative approach with effective mass yield and high reaction rates. Green Chem. Lett. Rev. 2010, 3, 217-223. [CrossRef]

33. Man, C.L.; Tin, W.C.; Wong, K.Y.; Tak, H.C. Synthetic and mechanistic studies of indium-mediated allylation of imines in ionic liquids. J. Org. Chem. 2007, 72, 923-929.

34. Ali, E.; Naimi-Jamal, M.R.; Dekamin, M.G. Highly efficient and rapid synthesis of imines in the presence of nano-ordered MCM-41-SO3H heterogeneous catalyst. Sci. Iran. 2013, 20, 592-597.

35. Vázquez, M.Á.; Landa, M.; Reyes, L.; Miranda, R.; Tamariz, J.; Delgado, F. Infrared irradiation: Effective promoter in the formation of N-benzylideneanilines in the absence of solvent. Synth. Commun. 2004, 34, 2705-2718. [CrossRef]

36. Guzen, K.P.; Guarezemini, A.S.; Órfão, A.T.G.; Cella, R.; Pereira, C.M.P.; Stefani, H.A. Eco-friendly synthesis of imines by ultrasound irradiation. Tetrahedron Lett. 2007, 48, 1845-1848. [CrossRef]

37. Gopalakrishnan, M.; Sureshkumar, P.; Kanagarajan, V.; Thanusu, J. New environmentally-friendly solvent-free synthesis of imines using calcium oxide under microwave irradiation. Res. Chem. Intermed. 2007, 33, 541-548. [CrossRef]

38. Schmeyers, J.; Toda, F.; Boy, J.; Kaupp, G. Quantitative solid-solid synthesis of azomethines. J. Chem. Soc. Perkin Trans. 2 1998, 4, 989-993. [CrossRef]

39. Khrushcheva, N.S.; Loim, N.M.; Sokolov, V.I. Solid-state synthesis of Schiff bases. Russ. Chem. Bull. 1997, 46, 1952-1955. [CrossRef]

40. Leoni, L.; Carletta, A.; Fusaro, L.; Dubois, J.; Tumanov, N.A.; Aprile, C.; Wouters, J.; Dalla Cort, A. A Simple and Efficient Mechanochemical Route for the Synthesis of Salophen Ligands and of the Corresponding Zn, $\mathrm{Ni}$, and Pd Complexes. Molecules 2019, 24, 2314. [CrossRef]

41. Houjou, H.; Hoga, Y.; Ma, Y.-L.; Achira, H.; Yoshikawa, I.; Mutai, T.; Matsumura, K. Dinuclear fused salen complexes of group-10 metals: Peculiarity of the crystal structure and near-infrared luminescence of a bis(Pt-salen) complex. Inorg. Chim. Acta 2017, 461, 27-34. [CrossRef] 
42. Achira, H.; Hoga, Y.; Yoshikawa, I.; Mutai, T.; Matsumura, K.; Houjou, H. Effects of a semiflexible linker on the mechanochromic photoluminescence of bis(Pt-salen) complex. Polyhedron 2016, 113, 123-131. [CrossRef]

43. Doistau, B.; Rossi-Gendron, C.; Tron, A.; McClenaghan, N.D.; Chamoreau, L.-M.; Hasenknopf, B.; Vives, G. Switchable platinum-based tweezers with $\mathrm{Pt}-\mathrm{Pt}$ bonding and selective luminescence quenching. Dalt. Trans. 2015, 44, 8543-8551. [CrossRef] [PubMed]

44. Miroslaw, B.; Cristóvão, B.; Hnatejko, Z. Structural, Luminescent and Thermal Properties of Heteronuclear PdII-LnIII-PdII Complexes of Hexadentate $\mathrm{N}_{2} \mathrm{O}_{4}$ Schiff Base Ligand. Molecules 2018, 23, 2423. [CrossRef]

45. Gao, J.; Reibenspies, J.H.; Zingaro, R.A.; Woolley, F.R.; Martell, A.E.; Clearfield, A. Novel chiral "calixsalen" macrocycle and chiral Robson-type macrocyclic complexes. Inorg. Chem. 2005, 44, 232-241. [CrossRef]

46. Ritter, E.; Przybylski, P.; Brzezinski, B.; Bartl, F. Schiff Bases in Biological Systems. Curr. Org. Chem. 2009, 13, 241-249. [CrossRef]

47. Wrodnigg, T.M.; Eder, B. The Amadori and Heyns Rearrangements: Landmarks in the History of Carbohydrate Chemistry or Unrecognized Synthetic Opportunities? In Glycoscience-Epimerization, Isomerization, Rearrangement Reactions of Carbohydratesistry; Stütz, A.E., Ed.; Springer: Berlin/Heidelberg, Germany, 2001; Volume 215, pp. 115-152. ISBN 3-540-41383-9.

48. Ge, S.J.; Lee, T.C. Kinetic Significance of the Schiff Base Reversion in the Early-Stage Maillard Reaction of a Phenylalanine-Glucose Aqueous Model System. J. Agric. Food Chem. 1997, 45, 1619-1623. [CrossRef]

49. Gao, A.; Liu, R. Reaction Mechanism of Schiff Base Formation in the Maillard Reaction. Int. J. Sci. Eng. Res. 2014, 5, 2139-2145.

50. Lund, M.N.; Ray, C.A. Control of Maillard Reactions in Foods: Strategies and Chemical Mechanisms. J. Agric. Food Chem. 2017, 65, 4537-4552. [CrossRef]

51. Kavitha, H. Biological activities of Schiff base and its complexes: A review. Rasayan J. Chem. 2010, 3, 385-410.

52. Saddam Hossain, M.; Kanti Roy, P.; Kudrat-E.-Zahan, M.; Md Kudrat-E-Zahan, C.; Zakaria, C. Selected Schiff base coordination complexes and their microbial application: A review. Int. J. Chem. Stud. 2018, 6, 19-31.

53. Malik, M.A.; Dar, O.A.; Gull, P.; Wani, M.Y.; Hashmi, A.A. Heterocyclic Schiff base transition metal complexes in antimicrobial and anticancer chemotherapy. Medchemcomm 2018, 9, 409-436. [CrossRef] [PubMed]

54. Abu-Dief, A.M.; Mohamed, I.M.A.A. A review on versatile applications of transition metal complexes incorporating Schiff bases. Beni-Suef Univ. J. Basic Appl. Sci. 2015, 4, 119-133. [CrossRef] [PubMed]

55. Przybylski, P.; Huczynski, A.; Pyta, K.; Brzezinski, B.; Bartl, F. Biological Properties of Schiff Bases and Azo Derivatives of Phenols. Curr. Org. Chem. 2009, 13, 124-148. [CrossRef]

56. Rocha, M.; Ruiz, M.C.; Echeverría, G.A.; Piro, O.E.; Di Virgilio, A.L.; León, I.E.; Frontera, A.; Gil, D.M. Diethylaminophenyl-based Schiff base $\mathrm{Cu}(\mathrm{ii})$ and V(iv) complexes: Experimental and theoretical studies and cytotoxicity assays. New J. Chem. 2019, 43, 18832-18842. [CrossRef]

57. Kajal, A.; Bala, S.; Kamboj, S.; Sharma, N.; Saini, V. Schiff Bases: A Versatile Pharmacophore. J. Catal. 2013, 2013, 1-14. [CrossRef]

58. Kumar, J.; Rai, A.; Raj, V. A Comprehensive Review on the Pharmacological Activity of Schiff Base Containing Derivatives. Org. Med. Chem. 2017, 1, 1-15.

59. de Fátima, Â.; de P. Pereira, C.; Olímpio, C.R.S.D.G.; de Freitas Oliveira, B.G.; Franco, L.L.; da Silva, P.H.C. Schiff bases and their metal complexes as urease inhibitors-A brief review. J. Adv. Res. 2018, 13, 113-126.

60. Sztanke, K.; Maziarka, A.; Osinka, A.; Sztanke, M. An insight into synthetic Schiff bases revealing antiproliferative activities in vitro. Bioorganic Med. Chem. 2013, 21, 3648-3666. [CrossRef]

61. Xu, J.; Liu, Y.; Hsu, S. Hydrogels Based on Schiff Base Linkages for Biomedical Applications. Molecules 2019, 24, 3005. [CrossRef]

62. Kaczmarek, M.T.; Zabiszak, M.; Nowak, M.; Jastrzab, R. Lanthanides: Schiff base complexes, applications in cancer diagnosis, therapy, and antibacterial activity. Coord. Chem. Rev. 2018, 370, 42-54. [CrossRef]

63. Majid, S.A.; Mir, J.M.; Paul, S.; Akhter, M.; Parray, H.; Ayoub, R.; Shalla, A.H. Experimental and molecular topology-based biological implications of Schiff base complexes: A concise review. Rev. Inorg. Chem. 2019, 39, 113-128. [CrossRef]

64. Brodowska, K.; Łodyga-Chruścińska, E. Schiff bases-Interesting range of applications in various fields of science. Chemik 2014, 68, 129-134.

65. Cozzi, P.G. Metal-Salen Schiff base complexes in catalysis: Practical aspects. Chem. Soc. Rev. 2004, 33, 410-421. [CrossRef]

66. Gualandi, A.; Calogero, F.; Potenti, S.; Cozzi, P.G. Al(Salen) Metal Complexes in Stereoselective Catalysis. Molecules 2019, 24, 1716. [CrossRef] 
67. Hosseini-Monfared, H.; Alavi, S.; Siczek, M. Synthesis, structural analysis and evaluation of the catalytic activity of a non-symmetric N-(salicylidene)diethylenetriamine complex of copper(II). Chin. J. Catal. 2013, 34, 1456-1461. [CrossRef]

68. Gupta, K.C.; Sutar, A.K. Catalytic activities of Schiff base transition metal complexes. Coord. Chem. Rev. 2008, 252, 1420-1450. [CrossRef]

69. Afrin Dalia, S.; Farhana Afsan, B.; Md Saddam Hossain, B.; Nuruzzaman Khan, M.; Md Kudrat-E-Zahan, B.; Md Mahasin Ali, B.; Md Kudrat-E-Zahan, C.; Afsan, F.; Saddam Hossain, M.; Zakaria, C.; et al. A short review on chemistry of schiff base metal complexes and their catalytic application. Int. J. Chem. Stud. 2018, 6, 2859-2866.

70. Pradeep, C.P.; Das, S.K. Coordination and supramolecular aspects of the metal complexes of chiral $\mathrm{N}$-salicyl- $\beta$-amino alcohol Schiff base ligands: Towards understanding the roles of weak interactions in their catalytic reactions. Coord. Chem. Rev. 2013, 257, 1699-1715. [CrossRef]

71. Zoubi, W. Al Review: Solvent extraction of metal ions by use of schiff bases. J. Coord. Chem. 2013, 66, $2264-2289$. [CrossRef]

72. Ghosh, P.; Dey, S.; Ara, M.; Karim, K.; Islam, A.B.M.N. A review on synthesis and versatile applications of some selected Schiff bases with their transition metal complexes. Egypt. J. Chem. 2020, 63, 5-6. [CrossRef]

73. Bilgin, A.; Çetintaş, S.; Cerrahoğlu, E.; Yildiz, U.; Bingöl, D. A new Schiff base: Synthesis, characterization and optimization of metal ions-binding properties. Sep. Sci. Technol. 2016, 51, 2138-2144. [CrossRef]

74. Berhanu, A.L.; Gaurav; Mohiuddin, I.; Malik, A.K.; Aulakh, J.S.; Kumar, V.; Kim, K.-H. A review of the applications of Schiff bases as optical chemical sensors. Trac. Trends Anal. Chem. 2019, 116, 74-91. [CrossRef]

75. Hijji, Y.M.; Barare, B.; Kennedy, A.P.; Butcher, R. Synthesis and photophysical characterization of a Schiff base as anion sensor. Sens. Actuators B Chem. 2009, 136, 297-302. [CrossRef]

76. Torawane, P.; Sahoo, S.K.; Borse, A.; Kuwar, A. A new Schiff base as a turn-off fluorescent sensor for $\mathrm{Cu}^{2+}$ and its photophysical properties. Luminescence 2017, 32, 1426-1430. [CrossRef]

77. Oiye, É.N.; Ribeiro, M.F.M.; Katayama, J.M.T.; Tadini, M.C.; Balbino, M.A.; Eleotério, I.C.; Magalhães, J.; Castro, A.S.; Silva, R.S.M.; da Cruz Júnior, J.W.; et al. Electrochemical Sensors Containing Schiff Bases and their Transition Metal Complexes to Detect Analytes of Forensic, Pharmaceutical and Environmental Interest. A Review. Crit. Rev. Anal. Chem. 2019, 49, 488-509. [CrossRef]

78. Vidyasagar, C.C.; Muñoz Flores, B.M.; Jiménez-Pérez, V.M.; Gurubasavaraj, P.M. Recent advances in boron-based schiff base derivatives for organic light-emitting diodes. Mater. Today Chem. 2019, 11, 133-155. [CrossRef]

79. Abbasi, Z.; Salehi, M.; Kubicki, M.; Khaleghian, A. Crystal structures, electrochemical properties, antioxidant screening and in vitro cytotoxic studies on four novel $\mathrm{Cu}(\mathrm{II})$ complexes of bidentate Schiff base ligands derived from 2-methoxyethylamine. J. Coord. Chem. 2017, 70, 2074-2093. [CrossRef]

80. Bikas, R.; Hosseini Monfared, H.; Lis, T.; Siczek, M. Synthesis, structural characterization and electrochemical studies of an ionic cobalt complex derived from a tridentate hydrazone Schiff base and azide ligands. Inorg. Chem. Commun. 2012, 15, 151-155. [CrossRef]

81. Zhang, Q.-C.; Xiao, H.; Zhang, X.; Xu, L.-J.; Chen, Z.-N. Luminescent oligonuclear metal complexes and the use in organic light-emitting diodes. Coord. Chem. Rev. 2019, 378, 121-133. [CrossRef]

82. Jimoh, A.A.; Helal, A.; Shaikh, M.N.; Abdul Aziz, M.; Yamani, Z.H.; Al-Ahmed, A.; Kim, J.P. Schiff base ligand coated gold nanoparticles for the chemical sensing of Fe(III) ions. J. Nanomater. 2015, 2015, 1-7. [CrossRef]

83. Faridbod, F.; Ganjali, M.; Dinarvand, R.; Norouzi, P.; Riahi, S. Schiff's Bases and Crown Ethers as Supramolecular Sensing Materials in the Construction of Potentiometric Membrane Sensors. Sensors 2008, 8, 1645-1703. [CrossRef]

84. Tsaturyan, A.; Machida, Y.; Akitsu, T.; Gozhikova, I.; Shcherbakov, I. Binaphthyl-containing Schiff base complexes with carboxyl groups for dye sensitized solar cell: An experimental and theoretical study. J. Mol. Struct. 2018, 1162, 54-62. [CrossRef]

85. Chouk, R.; Aguir, C.; Haouanoh, D.; Bergaoui, M.; Tala-Ighil, R.; Stathatos, E.; Khalfaoui, M. A first-principles computational and experimental investigation on schiff base cobalt complex towards designing solar cells. J. Mol. Struct. 2019, 1196, 676-684. [CrossRef] 
86. Kasmi-Mir, S.; ElKebich, M.; Dembahri, Z.; Haouzi, A.; Kirsch, G. Synthesis of new Schiff bases as materials for the design of photovoltaics cells. J. Fundam. Appl. Sci. 2016, 8, 569. [CrossRef]

87. Dong, Y.W.; Fan, R.Q.; Wang, P.; Wei, L.G.; Wang, X.M.; Zhang, H.J.; Gao, S.; Yang, Y.L.; Wang, Y.L. Synthesis and characterization of substituted Schiff-base ligands and their d10 metal complexes: Structure-induced luminescence tuning behaviors and applications in co-sensitized solar cells. Dalt. Trans. 2015, 44, 5306-5322. [CrossRef]

88. Zhang, J.; Xu, L.; Wong, W.-Y. Energy materials based on metal Schiff base complexes. Coord. Chem. Rev. 2018, 355, 180-198. [CrossRef]

89. Inorganics|Special Issue: Schiff-Base Metal Complexes. Available online: https://www.mdpi.com/journal/ inorganics/special_issues/schiff_base_metal_complexes (accessed on 24 March 2020).

90. Molecules|Special Issue: Schiff Base and Its Metal Complexes. Available online: https://www.mdpi.com/ journal/molecules/special_issues/schiff_base_metal (accessed on 24 March 2020).

91. Jain, V.K.; Jain, L. The chemistry of binuclear palladium(II) and platinum(II) complexes. Coord. Chem. Rev. 2005, 249, 3075-3197. [CrossRef]

92. Golbedaghi, R.; Fausto, R. Coordination aspects in Schiff bases cocrystals. Polyhedron 2018, 155, 1-12. [CrossRef]

93. Beck, W.; Sünkel, K. Metal Complexes of Indigo and of Some Related Ligands. Z. Für Anorg. Und Allg. Chem. 2020, 646, 248-255. [CrossRef]

94. Mondal, I.; Chattopadhyay, S. Development of multi-metallic complexes using metal-salen complexes as building blocks. J. Coord. Chem. 2019, 72, 3183-3209. [CrossRef]

95. Karmakar, M.; Chattopadhyay, S. A comprehensive overview of the orientation of tetradentate $\mathrm{N}_{2} \mathrm{O}_{2}$ donor Schiff base ligands in octahedral complexes of trivalent 3d metals. J. Mol. Struct. 2019, 1186, 155-186. [CrossRef]

96. Selvi, G.; Özdemir, F.A.; Aykutoglu, G.; Özdemir, N.; Şerbetçi, Z.; Çetinkaya, B.; Dayan, O. A neutral arene ruthenium(II) complex with a sulfonated $\mathrm{N}, \mathrm{O}$-chelating ligand: Synthesis, characterization, in vitro cytotoxicity and antibacterial activity. Polyhedron 2020, 176, 114300. [CrossRef]

97. Maher, K.A.; Mohammes, S.R. Metal complexes of Schiff base derived from a new Mannich base. Int. J. Chemtech Res. 2015, 8, 937-943.

98. Tsantis, S.T.; Tzimopoulos, D.I.; Holynska, M.; Perlepes, S.P. Oligonuclear Actinoid Complexes with Schiff Bases as Ligands-Older Achievements and Recent Progress. Int. J. Mol. Sci. 2020, 21, 555. [CrossRef]

99. Wojaczyński, J.; Latos-Grazyński, L. Poly- and oligometalloporphyrins associated through coordination. Coord. Chem. Rev. 2000, 204, 113-171. [CrossRef]

100. Mahmoudi, G.; Khandar, A.A.; Afkhami, F.A.; Miroslaw, B.; Gurbanov, A.V.; Zubkov, F.I.; Kennedy, A.; Franconetti, A.; Frontera, A. Modulation of coordination in pincer-type isonicotinohydrazone Schiff base ligands by proton transfer. CrystEngComm 2019, 21, 108-117. [CrossRef]

101. Filarowski, A.; Koll, A.; Sobczyk, L. Intramolecular Hydrogen Bonding in o-hydroxy Aryl Schiff Bases. Curr. Org. Chem. 2009, 13, 172-193. [CrossRef]

102. Biswas, D.; Chakrabarty, P.P.; Saha, S.; Jana, A.D.; Schollmeyer, D.; García-Granda, S. Ligand mediated structural diversity and role of different weak interactions in molecular self-assembly of a series of copper(II)-sodium(I) Schiff-base heterometallic complexes. Inorg. Chim. Acta 2013, 408, 172-180. [CrossRef]

103. Dziembowska, T. Resonance assisted intramolecular hydrogen bond in schiff bases. Pol. J. Chem. 1998, 72, 193-209.

104. Cristóvão, B.; Miroslaw, B. Tautomerism of a compartmental Schiff base ligand and characterization of a new heterometallic CuII-DyIII complex-Synthesis, structure and magnetic properties. Inorg. Chem. Commun. 2015, 52, 64-68. [CrossRef]

105. Mahmoudi, G.; Zarȩba, J.K.; Bauzá, A.; Kubicki, M.; Bartyzel, A.; Keramidas, A.D.; Butusov, L.; Mirosław, B.; Frontera, A. Recurrent supramolecular motifs in discrete complexes and coordination polymers based on mercury halides: Prevalence of chelate ring stacking and substituent effects. CrystEngComm 2018, 20, 1065-1076. [CrossRef]

106. Mahmoudi, G.; Bauzá, A.; Gurbanov, A.V.; Zubkov, F.I.; Maniukiewicz, W.; Rodríguez-Diéguez, A.; López-Torres, E.; Frontera, A. The role of unconventional stacking interactions in the supramolecular assemblies of $\mathrm{Hg}$ (ii) coordination compounds. CrystEngComm 2016, 18, 9056-9066. [CrossRef] 
107. Jia, Y.; Li, J. Molecular assembly of Schiff base interactions: Construction and application. Chem. Rev. 2015, 115, 1597-1621. [CrossRef]

108. Filarowski, A.; Glowiak, T.; Koll, A. Strengthening of the intramolecular O $\cdots \mathrm{H} \cdots \mathrm{N}$ hydrogen bonds in Schiff bases as a result of steric repulsion. J. Mol. Struct. 1999, 484, 75-89. [CrossRef]

109. Cook, A.W.; Hrobárik, P.; Damon, P.L.; Wu, G.; Hayton, T.W. A Ketimide-Stabilized Palladium Nanocluster with a Hexagonal Aromatic Pd7 Core. Inorg. Chem. 2020, 59, 1471-1480. [CrossRef]

110. Jin, R. Atomically precise metal nanoclusters: Stable sizes and optical properties. Nanoscale 2015, 7, 1549-1565. [CrossRef]

111. Du, X.; Jin, R. Atomically Precise Metal Nanoclusters for Catalysis. ACS Nano 2019, 13, 7383-7387. [CrossRef]

112. Du, Y.; Sheng, H.; Astruc, D.; Zhu, M. Atomically Precise Noble Metal Nanoclusters as Efficient Catalysts: A Bridge between Structure and Properties. Chem. Rev. 2020, 120, 526-622. [CrossRef]

113. Cook, A.W.; Hrobárik, P.; Damon, P.L.; Najera, D.; Horváth, B.; Wu, G.; Hayton, T.W. Synthesis and Characterization of a Linear, Two-Coordinate Pt(II) Ketimide Complex. Inorg. Chem. 2019, 58, 15927-15935. [CrossRef]

114. Das, A.; Chen, Y.S.; Reibenspies, J.H.; Powers, D.C. Characterization of a Reactive Rh2 Nitrenoid by Crystalline Matrix Isolation. J. Am. Chem. Soc. 2019, 141, 16232-16236. [CrossRef]

115. Allscher, T.; Kästele, X.; Kettenbach, G.; Klüfers, P.; Kunte, T. Sugar-Alcohol Complexes of Palladium(II): On the Variable Rigidity of Open-Chain Carbohydrate Ligands. Chem. Asian J. 2007, 2, 1037-1045. [CrossRef]

116. Werner, H.; Müller, M.; Steinert, P. Synthese, Molekülstruktur und Reaktivität neutraler und kationischer Iridium-Zweikernkomplexe mit verbrückenden Azavinylidenliganden. Z. Für Anorg. Und Allg. Chem. 2003, 629, 1337-1346. [CrossRef]

117. Galsworthy, J.R.; Housecroft, C.E.; Humphrey, J.S.; Song, X.; Edwards, A.J.; Rheingold, A.L. Boron-nitrogen coupling in a ruthenium-rich ruthenaborane cluster: Synthesis, and molecular and electronic structures of $\left[\mathrm{Ru}_{4} \mathrm{H}(\mathrm{CO}){ }_{12} \mathrm{BH}(\mu-\mathrm{NCHMe})\right]$. J. Chem. Soc. Dalt. Trans. 1994, 3273-3277. [CrossRef]

118. Esteruelas, M.A.; Lahoz, F.J.; Oliván, M.; Onate, E.; Oro, L.A. Azavinylidene and Azavinylidene-Bridged Compounds of Iridium and Rhodium. Organometallics 1994, 13, 3315-3323. [CrossRef]

119. Kuwabara, J.; Takeuchi, D.; Osakada, K. Preparation and properties of $\mathrm{Cp}_{2} \mathrm{Zr}(\mu-\mathrm{N}=\mathrm{CAr} 2) 2 \mathrm{PdCl}(\mathrm{Me})$, new $\mathrm{Zr} / \mathrm{Pd}$ heterobimetallic complexes with bridging alkylideneamido ligands. Organometallics 2004, 23, 5092-5095. [CrossRef]

120. Ruiz, J.; Rodríguez, V.; Cutillas, N.; Florenciano, F.; Pérez, J.; López, G. First complex containing a $\mathrm{Pd}_{2}\left(\mu 2-\mathrm{N}=\mathrm{CPh}_{2}\right)_{2}$ functional group. Inorg. Chem. Commun. 2001, 4, 23-25. [CrossRef]

121. Sun, Z.-M.; Chen, S.-P.; Zhao, P. Tertiary Carbinamine Synthesis by Rhodium-Catalyzed [3+2] Annulation of N-Unsubstituted Aromatic Ketimines and Alkynes. Chemistry 2010, 16, 2619-2627. [CrossRef]

122. Anillo, A.; Díaz, M.R.; García-Granda, S.; Obeso-Rosete, R.; Galindo, A.; Ienco, A.; Mealli, C. Structural and electronic rearrangements upon the oxidation of binuclear $\left(\mathrm{Ru}_{2}\right)$ and trinuclear $\left(\mathrm{MoRu}_{2}\right)$ complexes with bridging o-phenylenediamido ligands. Organometallics 2004, 23, 471-481. [CrossRef]

123. Chatterjee, S.; Mandal, S.; Samanta, S.; Goswami, S. Bis(acetonitrile)bis(acetylacetonato)ruthenium(iii) mediated chemical transformations of coordinated 2-methylthioanilide. Dalt. Trans. 2012, 41, 7057-7066. [CrossRef]

124. Kaim, W. Manifestations of noninnocent ligand behavior. Inorg. Chem. 2011, 50, 9752-9765. [CrossRef]

125. Kasack, V.; Kaim, W.; Binder, H.; Jordanov, J.; Roth, E. When Is an Odd-Electron Dinuclear Complex a Mixed-Valent Species? Tuning of Ligand-to-Metal Spin Shifts in Diruthenium(III,II) Complexes of Noninnocent Bridging Ligands OC(R) NNC(R) O. Inorg. Chem. 1995, 34, 1924-1933. [CrossRef]

126. Bernadou, J.; Meunier, B.; Fabiano, A.S.; Robert, A. “Redox Tautomerism” in High-Valent Metal-oxo-aquo Complexes. Origin of the Oxygen Atom in Epoxidation Reactions Catalyzed by Water-Soluble Metalloporphyrins. J. Am. Chem. Soc. 1994, 116, 9375-9376. [CrossRef]

127. Ward, M.D.; McCleverty, J.A. Non-innocent behaviour in mononuclear and polynuclear complexes: Consequences for redox and electronic spectroscopic properties. J. Chem. Soc. Dalt. Trans. 2002, 3, 275-288. [CrossRef]

128. Kaim, W.; Schwederski, B. Non-innocent ligands in bioinorganic chemistry-An overview. Coord. Chem. Rev. 2010, 254, 1580-1588. [CrossRef]

129. Kaim, W. Chelate rings of different sizes with non-innocent ligands. Dalt. Trans. 2019, 48, 8521-8529. [CrossRef]

130. Van Der Poel, H.; Van Koten, G.; Vrieze, K.; Kokkes, M.; Stam, C.H. Synthesis and molecular geometry of [trans- $\left.\mathrm{PtCl}_{2} \mathrm{PBu}_{3}\right]_{2}$ (di-t-Bu-diimine) containing a $\sigma, \sigma^{\prime}-\mathrm{N}, \mathrm{N}^{\prime}$ bridging diimine with a planar anti-(trans-PPNCCNPtPtrans)- skeleton. Inorg. Chim. Acta 1980, 39, 197-205. [CrossRef] 
131. Dieck, H.T.; Klaus, J. Diazadien-rhodium-komplexe. III. Konformationsstabilität durch rhodium(I) … H-C-wechselwirkungen. Festkörper- und lösungsstruktur von [(1,5-cod)RhCl]2( $\mu$-dad). J. Organomet. Chem. 1983, 246, 301-308. [CrossRef]

132. Clark, H.C.; Ferguson, G.; Jain, V.K.; Parvez, M. Cleavage Reactions of Halogen-Bridged Heterobimetallic Palladium-Platinum Complexes. Crystal and Molecular Structure of $\left[\left(\mathrm{P}-\mathrm{n}-\mathrm{Bu}_{3}\right) \mathrm{Cl}_{2} \mathrm{Pd}(\mathrm{t}-\mathrm{BuN}=\mathrm{CHCH}=\mathrm{N}-\mathrm{t}\right.$ -Bu) $\mathrm{PtCl}_{2}\left(\mathrm{P}-\mathrm{n}-\mathrm{Bu}_{3}\right)$ ]. Inorg. Chem. 1986, 25, 3808-3811. [CrossRef]

133. Burford, R.J.; Piers, W.E.; Parvez, M. Acetonitrile Coupling at an Electron-Rich Iridium Center Supported by a PC sp 2P Pincer Ligand. Eur. J. Inorg. Chem. 2013, 2013, 3826-3830. [CrossRef]

134. Khan, F.F.; Sobottka, S.; Sarkar, B.; Lahiri, G.K. Redox-Induced Oxidative C-C Bond Cleavage of 2,2'-Pyridil in Diruthenium Complexes. Chemistry 2019, 25, 9737-9746. [CrossRef]

135. Zhai, F.; Solomon, J.B.; Jordan, R.F. Copolymerization of Ethylene with Acrylate Monomers by Amide-Functionalized $\alpha$-Diimine Pd Catalysts. Organometallics 2017, 36, 1873-1879. [CrossRef]

136. Mandal, S.; Samanta, S.; Mondal, T.K.; Goswami, S. Comparative study on ortho-C-H vs ortho-C-X (X=C, $\mathrm{Cl}$, $\mathrm{S})$ bond activation in ortho-C aromatic-N bond fusion in substituted anilines using ruthenium(II) mediators: Isolation and characterization of unusual Ru 2 complexes. Organometallics 2012, 31, 5282-5293. [CrossRef]

137. Fomina, I.G.; Sidorov, A.A.; Aleksandrov, G.G.; Nefedov, S.E.; Eremenko, I.L.; Moiseev, I.I. Deprotonated N-phenyl-o-phenylenediimine as a bridging ligand. J. Organomet. Chem. 2001, 636, 157-163. [CrossRef]

138. Dybała, I.; Demchuk, O.M. Tris(acetonitrile)chloropalladium tetrafluoroborate synthesis, application and structural analysis. J. Mol. Struct. 2016, 1121, 135-141. [CrossRef]

139. Demchuk, O.M.; Kielar, K.; Pietrusiewicz, K.M. Rational design of novel ligands for environmentally benign cross-coupling reactions. Pure Appl. Chem. 2011, 83, 633-644. [CrossRef]

140. Pietrusiewicz, K.; Szwaczko, K.; Mirosław, B.; Dybała, I.; Jasiński, R.; Demchuk, O.; Pietrusiewicz, K.M.; Szwaczko, K.; Mirosław, B.; Dybała, I.; et al. New Rigid Polycyclic Bis(phosphane) for Asymmetric Catalysis. Molecules 2019, 24, 571. [CrossRef]

141. Ghosh, P.; Dey, S.; Panda, S.; Lahiri, G.K. Solvent-Mediated Functionalization of Benzofuroxan on Electron-Rich Ruthenium Complex Platform. Chemistry 2018, 13, 1582-1593. [CrossRef]

142. Abbel, R.; Abdur-Rashid, K.; Faatz, M.; Hadzovic, A.; Lough, A.J.; Morris, R.H. A succession of isomers of ruthenium dihydride complexes. Which one is the ketone hydrogenation catalyst? J. Am. Chem. Soc. 2005, 127, 1870-1882. [CrossRef]

143. Keijsper, J.; Polm, L.H.; van Koten, G.; Vrieze, K.; Nielsen, E.; Stam, C.H. Ruthenium Carbonyl 1, 4-Diaza-1, 3-butadiene (R-DAB) Complexes.1 Reactivity of $\mathrm{Ru}_{2}(\mathrm{CO})_{5}(\mathrm{R}-\mathrm{DAB})$ toward Molecular Hydrogen. Molecular Structure of $\mathrm{H}_{2} \mathrm{Ru}_{4}(\mathrm{CO})_{8}(\mathrm{R}-\mathrm{DAB})_{2}$, Containing an Unique Linear Chain of Four Ruthenium Atoms. Organometallics 1985, 4, 2006-2012. [CrossRef]

144. Zoet, R.; van Koten, G.; Stufkens, D.J.; Vrieze, K.; Stam, C.H. Conversion of 48e Os $3(\mathrm{CO})_{10}(\mathrm{R}-\mathrm{DAB}(4 \mathrm{e}))$ via $50 \mathrm{e} \mathrm{Os} 3(\mathrm{CO})_{10}(\mathrm{R}-\mathrm{DAB}(6 \mathrm{e}))$ to $50 \mathrm{e} \mathrm{Os}_{3}(\mathrm{CO})_{9}(\mathrm{R}-\mathrm{DAB}(8 \mathrm{e}))(\mathrm{R}-\mathrm{DAB}=\mathrm{RN}=\mathrm{C}(\mathrm{H}) \mathrm{C}(\mathrm{H})=\mathrm{NR}) .1 \mathrm{X}$-ray Structure of $\mathrm{Os}_{3}(\mathrm{CO})_{9}(\mathrm{i}-\mathrm{Pr}-\mathrm{DAB}(8 \mathrm{e}))$, with Two Elongated Os-Os Bonds. Organometallics 1988, 7, 2118-2123. [CrossRef]

145. Staal, L.H.; Van KOTEN, G.; Vrieze, K.; Ploeger, F.; Stam, C.H. Binuclear Metal Carbonyl DAB Complexes. 9. Syntheses and X-ray Structure of ( $\mu$-Acetylene)-[ $\sigma-\mathrm{N} \sigma-\mathrm{N}, \eta 2-\mathrm{C}=\mathrm{N}, \eta 2-\mathrm{C}=\mathrm{N}^{\prime}$-glyoxal bis(isopropylimine)] tetracarbonyldiruthenium. First Example of the 8e-Donating DAB Ligand (DAB =1,4-Diazabutadiene). Inorg. Chem. 1981, 20, 1830-1835. [CrossRef]

146. Staal, L.H.; Polm, L.H.; Vrieze, K.; Ploeger, F.; Stam, C.H. Influence of a Branching of the 1,4-Substituents on the Coordination of 1,4-Diazabutadienes in Mono-, Bi-, Tri-, and Tetranuclear Ruthenium Carbonyl Complexes. Crystal Structure of $\left[\sigma-\mathrm{N}, \sigma-\mathrm{N}^{\prime}, \eta 2-\mathrm{C}=\mathrm{N}, \eta 2-\mathrm{C}=\mathrm{N}^{\prime}\right.$-Diglyoxal bis(isopropylimine) ]octacarbonyltetraruthenium. Inorg. Chem. 1981, 20, 3590-3597.

147. Kraakman, M.J.A.; Elsevier, C.J.; de Haar, V.W.; Vrieze, K.; Spek, A.L. Synthesis of the monohydride complexes $\mathrm{HRu}_{2}(\mathrm{X})(\mathrm{CO})_{5}(\mathrm{iPr}-\mathrm{NCHCHN}-\mathrm{Pr})(\mathrm{X}=\mathrm{Cl}, \mathrm{I})$; hydrogenation of the central CC bond of the coordinated $\alpha$-diimine ligands. $\mathrm{X}$-ray. single crystal structure of $\mathrm{HRu}_{2}(\mathrm{Cl})(\mathrm{CO})_{5}(\mathrm{iPr}-\mathrm{NCHCHN}-\mathrm{PPr})$. Inorg. Chim. Acta 1993, 203, 157-170. [CrossRef]

148. Owen, G.R.; Vilar, R.; White, A.J.P.; Williams, D.J. Synthesis and structural characterization of a novel dipalladium complex with an unprecedented PdCN bonding motif. Organometallics 2003, 22, 3025-3027. [CrossRef]

149. Zoet, R.; Jastrzebski, J.T.; van Koten, G.; Mahabiersing, T.; Vrieze, K.; Heijdenrijk, D.; Stam, C.H. Synthesis and Characterization of Two Isomers of Decacarbonyl( 1,4-dialkyl-1,4-diaza-1,3-butadiene) triosmium: 
$\mathrm{Os}_{3}(\mathrm{CO})_{10}(\mathrm{R}-\mathrm{DAB}) .1$ Fluxional Behavior of $\mathrm{Os}_{3}(\mathrm{CO})_{10}(\mathrm{i}-\mathrm{Pr}-\mathrm{DAB}(4 \mathrm{e}))$. Molecular Structures of the $48 \mathrm{e}$ Cluster $\mathrm{Os}_{3}(\mathrm{CO})_{10}(\mathrm{i}-\mathrm{Pr}-\mathrm{DAB}(4 \mathrm{e}))$ and of the $50 \mathrm{e}$ Cluster $\mathrm{Os}_{3}(\mathrm{CO})_{10}(\mathrm{c}-\mathrm{Pr}-\mathrm{DAB}(6 \mathrm{e}))$ Containing a $4 \mathrm{e}$ Donor $\sigma, \sigma-\mathrm{N}, \mathrm{N}^{\prime}$ and a 6 e Donor $\sigma-\mathrm{N}, \mu 2-\mathrm{N}^{\prime}, \eta 2-\mathrm{C}=\mathrm{N}^{\prime}$ Bonded R-DAB Ligand, Respectively. Organometallics 1988, 7, 2108-2117.

150. Trincado, M.; Sinha, V.; Rodriguez-Lugo, R.E.; Pribanic, B.; De Bruin, B.; Grützmacher, H. Homogeneously catalysed conversion of aqueous formaldehyde to $\mathrm{H}_{2}$ and carbonate. Nat. Commun. 2017, 8, 1-11. [CrossRef]

151. Zhou, J.; Sun, H.; Harms, K.; Sundermeyer, J. Synthesis and X-ray Crystal Structures of Acenaphthenequinone-based $\alpha$-Diimine Palladium Complexes and a Novel V-shape Tripalladium Cluster. Z. Für Anorg. Und Allg. Chem. 2008, 634, 1517-1521. [CrossRef]

152. Bourget-Merle, L.; Lappert, M.F.; Severn, J.R. The chemistry of $\beta$-diketiminatometal complexes. Chem. Rev. 2002, 102, 3031-3065. [CrossRef]

153. Singh, A.; Chandra, M.; Sahay, A.N.; Pandey, D.S.; Pandey, K.K.; Mobin, S.M.; Puerta, M.C.; Valerga, P. Arene ruthenium complexes incorporating immine/azine hybrid-chelating $\mathrm{N}-\mathrm{N}^{\prime}$ donor ligands: Synthetic, spectral, structural aspects and DFT studies. J. Organomet. Chem. 2004, 689, 1821-1834. [CrossRef]

154. Reinhart, E.D.; Jordan, R.F. Template-Free Synthesis of a Macrocyclic Bis(pyridine-dienamine) Proligand and Metal Complexes of Its Bis(pyridine-diimine) and Bis(pyridine-dienamido) Forms. Inorg. Chem. 2019, 58, 15466-15478. [CrossRef]

155. Mohamed Kasim, M.S.; Sundar, S.; Rengan, R. Synthesis and structure of new binuclear ruthenium(II) arene benzil bis(benzoylhydrazone) complexes: Investigation on antiproliferative activity and apoptosis induction. Inorg. Chem. Front. 2018, 5, 585-596. [CrossRef]

156. Yamaguchi, T.; Nishimura, N.; Shirakura, K.I.; Ito, T. Triangular platinum(II) cluster complexes and cluster core transformation from square-planar to triangular type. Bull. Chem. Soc. Jpn. 2000, 73, 775-784. [CrossRef]

157. Lee, J.H.; Im, S.Y.; Lee, S.W. Pd-Ln and Pt-Ln complexes of a bi-compartmental ligand: [MLn( $\left.(\mathrm{L})\left(\mathrm{NO}_{3}\right)_{3}\right]$ $\left(\mathrm{M}=\mathrm{Pd}, \mathrm{Pt} ; \mathrm{Ln}=\mathrm{Eu}, \mathrm{Tb} ; \mathrm{H} 2 \mathrm{~L}=\mathrm{N}, \mathrm{N}^{\prime}\right.$-bis(3-methoxysalicylidenimino-1,3-diaminopropane)). Inorg. Chim. Acta 2018, 474, 89-95. [CrossRef]

158. Man, W.-L.; Chen, G.; Yiu, S.-M.; Shek, L.; Wong, W.-Y.; Wong, W.-T.; Lau, T.-C. Formation of $\mu$-dinitrogen (salen)osmium complexes via ligand-induced $\mathrm{N} \cdots \mathrm{N}$ coupling of (salen)osmium(vi) nitrides. Dalt. Trans. 2010, 39, 11163. [CrossRef]

159. Ru, J.; Zhang, R.-F.; Shi, Y.; Zhang, S.-L.; Li, Q.-L.; Ma, C.-L. Synthesis, structures and magnetic properties of heterobimetallic $\mathrm{Ru}^{\mathrm{III}}-3 \mathrm{~d}(3 \mathrm{~d}=\mathrm{Mn}, \mathrm{Ni})$ compounds based on the chiral Ru ${ }^{\mathrm{III}}$ building block. New J. Chem. 2018, 42, 16237-16243. [CrossRef]

160. Piñero Cruz, D.M.; Woodruff, D.N.; Jeon, I.-R.; Bhowmick, I.; Secu, M.; Hillard, E.A.; Dechambenoit, P.; Clérac, R. Switching off the single-molecule magnet properties of the $\left[\mathrm{Co}{ }^{\mathrm{II}}\left(\mathrm{Me}_{6} \text { tren }\right)\left(\mathrm{OH}_{2}\right)\right]^{2+}$ module by complexation with trans $-\left[\mathrm{Ru} \text { III (salen) }(\mathrm{CN})_{2}\right]^{-}$. New J. Chem. 2014, 38, 3443-3448. [CrossRef]

161. Zhang, D.; Cano, J.; Lan, W.; Liu, H.; Sun, F.; Dong, Y.; Zhou, Z.; Yang, L.; Liu, Q.; Jiang, J. Unconventional dihydrogen-bond interaction induced cyanide-bridged chiral nano-sized magnetic molecular wheel: Synthesis, crystal structure and systematic theoretical magnetism investigation. J. Mater. Chem. C 2019, 7, 3623-3633. [CrossRef]

162. Cristóvão, B.; Miroslaw, B. Propeller-like heterotrinuclear CuII-LnIII-CuII compounds-Physicochemical properties. Inorg. Chim. Acta 2013, 401, 50-57. [CrossRef]

163. Cristóvão, B.; Miroslaw, B. Asymmetry in propeller-like trinuclear diphenoxo-bridged CuII-LnIII-CuII ( $\mathrm{Ln}=\mathrm{La}, \mathrm{Pr}, \mathrm{Nd}$ ) Schiff base complexes—synthesis, structure and magnetic properties. J. Coord. Chem. 2015, 68, 1602-1615. [CrossRef]

164. Rigamonti, L.; Forni, A. Effect of crystal packing and coordinated solvent molecules on metal-ligand bond distances in linear trinuclear nickel compounds with bridging acetato and Schiff base ligands. Inorg. Chim. Acta 2018, 473, 216-222. [CrossRef]

165. Miroslaw, B.; Cristóvão, B.; Hnatejko, Z. Heterometallic ZnII-LnIII-ZnII Schiff Base Complexes with Linear or Bent Conformation-Synthesis, Crystal Structures, Luminescent and Magnetic Characterization. Molecules 2018, 23, 1761. [CrossRef] [PubMed]

166. Miroslaw, B.; Cristóvão, B.; Hnatejko, Z. Halogen bonded lamellar motifs in crystals of Schiff base ZnII-LnIII-ZnII coordination compounds-Synthesis, structure, Hirshfeld surface analysis and physicochemical properties. Polyhedron 2019, 166, 83-90. [CrossRef]

167. Chen, G.; Man, W.-L.; Yiu, S.-M.; Wong, T.-W.; Szeto, L.; Wong, W.-T.; Lau, T.-C. Binuclear (salen)osmium phosphinidine and phosphiniminato complexes. Dalt. Trans. 2011, 40, 1938. [CrossRef] [PubMed] 
168. Marinescu, G.; Madalan, A.M.; Maxim, C.; Shova, S.; Clérac, R.; Andruh, M. Heterometallic 3d-4d coordination polymers assembled from: Trans -[RuIII(L)(CN)2]- tectons and 3d cations. Dalt. Trans. 2019, 48, 15455-15464. [CrossRef]

169. Pichon, C.; Dechambenoit, P.; Clérac, R. A cyanido-bridged two-dimensional network based on a RuIII schiff base complex and MnII ions: Synthesis, crystal structure and magnetic properties. Polyhedron 2013, 52, 476-481. [CrossRef]

170. Shatruk, M.; Avendano, C.; Dunbar, K.R. Cyanide-Bridged Complexes of Transition Metals: A Molecular Magnetism Perspective. In Progress in Inorganic Chemistry; Karlin, K.D., Ed.; John Wiley \& Sons, Inc.: Hoboken, NJ, USA, 2009; Volume 56, pp. 155-334.

171. Yeung, W.F.; Lau, P.H.; Lau, T.C.; Wei, H.Y.; Sun, H.L.; Gao, S.; Da Chen, Z.; Wong, W.T. Heterometallic MIIRuIII2 compounds constructed from trans-[Ru(Salen $\left.(\mathrm{CN})_{2}\right]-$ and trans-[Ru(Acac $\left.)_{2}(\mathrm{CN})_{2}\right]-$. Synthesis, structures, magnetic properties, and density functional theoretical study. Inorg. Chem. 2005, 44, 6579-6590. [CrossRef]

172. Cook, T.R.; Stang, P.J. Recent Developments in the Preparation and Chemistry of Metallacycles and Metallacages via Coordination. Chem. Rev. 2015, 115, 7001-7045. [CrossRef]

173. Reinhard, D.; Zhang, W.S.; Rominger, F.; Curticean, R.; Wacker, I.; Schröder, R.R.; Mastalerz, M. Discrete triptycene-based hexakis(Metalsalphens): Extrinsic soluble porous molecules of isostructural constitution. Chemistry 2018, 24, 11433-11437. [CrossRef]

174. Schmid, J.; Frey, W.; Peters, R. Polynuclear Enantiopure Salen-Mesoionic Carbene Hybrid Complexes. Organometallics 2017, 36, 4313-4324. [CrossRef]

175. Akine, S.; Nabeshima, T. Cyclic and acyclic oligo $\left(\mathrm{N}_{2} \mathrm{O}_{2}\right)$ ligands for cooperative multi-metal complexation. J. Chem. Soc. Dalt. Trans. 2009, 10395-10408. [CrossRef]

176. Li, Z.; Jablonski, C. Synthesis and characterization of "calixsalens": A new class of macrocyclic chiral ligands. Chem. Commun. 1999, 1531-1532. [CrossRef]

177. Kwit, M.; Gawronski, J. Chiral calixsalen-type macrocycles from trans-1,2-diaminocyclohexane. Tetrahedron Asymmetry 2003, 14, 1303-1308. [CrossRef]

178. Gawroński, J.; Kołbon, H.; Kwit, M.; Katrusiak, A. Designing large triangular chiral macrocycles: Efficient [3 + 3] diamine-dialdehyde condensations based on conformational bias. J. Org. Chem. 2000, 65, 5768-5773. [CrossRef] [PubMed]

179. Starynowicz, P.P.; Lisowski, J. A heterodinuclear macrocyclic complex containing both nickel(II) and palladium(II) ions. Chem. Commun. 1999, 769-770. [CrossRef]

180. Panther, T.; Behrens, U. Heterodinukleare Cobalt(II)-, Nickel(II)-, Kupfer(II)-, Zink(II)und Palladium(II) -Komplexe mit einem makrocyclischen Liganden vom Schiff-Basen-Typ: Synthesen und Strukturen. Z. Für Anorg. Und Allg. Chem. 2000, 626, 1934-1941. [CrossRef]

181. Akine, S.; Utsuno, F.; Piao, S.; Orita, H.; Tsuzuki, S.; Nabeshima, T. Synthesis, Ion Recognition Ability, and Metal-Assisted Aggregation Behavior of Dinuclear Metallohosts Having a Bis(Saloph) Macrocyclic Ligand. Inorg. Chem. 2016, 55, 810-821. [CrossRef]

182. Bokare, A.D.; Patnaik, A. Crystal structure of an ammonium thiocyanate complex of 18-crown-6. Cryst. Res. Technol. 2004, 39, 465-469. [CrossRef]

183. Doistau, B.; Tron, A.; Denisov, S.A.; Jonusauskas, G.; McClenaghan, N.D.; Gontard, G.; Marvaud, V.; Hasenknopf, B.; Vives, G. Terpy(Pt-salphen) 2 Switchable Luminescent Molecular Tweezers. Chemistry 2014, 20, 15799-15807. [CrossRef]

184. Ikeshita, M.; Ito, M.; Naota, T. Variations in the Solid-State Emissions of Clothespin-Shaped Binuclear trans -Bis(salicylaldiminato)platinum(II) with Halogen Functionalities. Eur. J. Inorg. Chem. 2019, 2019, 3561-3571. [CrossRef]

185. Yoon, I.; Goto, M.; Shimizu, T.; Lee, S.S.; Asakawa, M. Synthesis and characterisation of macrocyclic palladium( ii )-sodium( i ) complexes: Generation of an unusual metal-mediated electron delocalisation. Dalt. Trans. 2004, 1513-1515. [CrossRef]

186. Borisova, N.E.; Askerov, R.K.O.; Maharramov, A.M.; Khrustalev, V.N.; Reshetova, M.D.; Ustunyuk, Y.A. Self-assembly of a palladium complex formed from two U-shaped calixsalen molecules. Dalt. Trans. 2010, 39, 5768-5771. [CrossRef] 
187. Tong, W.-L.L.; Yiu, S.-M.M.; Chan, M.C.W.W. Crowded bis-(M-salphen) [M= Pt(II), Zn(II)] coordination architectures: Luminescent properties and ion-selective responses. Inorg. Chem. 2013, 52, 7114-7124. [CrossRef]

188. Naito, M.; Souda, H.; Koori, H.; Komiya, N.; Naota, T. Binuclear trans -Bis( $\beta$-iminoaryloxy)palladium(II) Complexes Doubly Linked with Pentamethylene Spacers: Structure-Dependent Flapping Motion and Heterochiral Association Behavior of the Clothespin-Shaped Molecules. Chemistry 2014, 20, 6991-7000. [CrossRef]

189. Naito, M.; Komiya, N.; Naota, T. Homochiral association of binuclear trans-bis( $\beta$-iminoaryloxy)palladium(ii) complexes doubly linked with m-xylylene spacers: Drastic linker-dependence of the association chirality of chiral clothespin-shaped molecules. Org. Chem. Front. 2016, 3, 1286-1294. [CrossRef]

190. Goshe, A.J.; Steele, I.M.; Bosnich, B. Supramolecular recognition: Association of palladium molecular clefts with planar platinum complexes. Inorg. Chim. Acta 2004, 357, 4544-4551. [CrossRef]

191. Liu, J.J.; Lin, Y.J.; Li, Z.H.; Jin, G.X. Self-assembled half-sandwich polyhedral cages: Via flexible Schiff-base ligands: An unusual macrocycle-to-cage conversion. Dalt. Trans. 2016, 45, 13675-13679. [CrossRef]

192. Frischmann, P.D.; Sahli, B.J.; Guieu, S.; Patrick, B.O.; MacLachlan, M.J. Sterically-Limited Self-Assembly of $\mathrm{Pt}_{4}$ Macrocycles into Discrete Non-covalent Nanotubes: Porous Supramolecular Tetramers and Hexamers. Chemistry 2012, 18, 13712-13721. [CrossRef] [PubMed]

193. Madalan, A.M.; Avarvari, N.; Andruh, M. Metal complexes as second-sphere ligands. New J. Chem. 2006, 30, 521. [CrossRef]

194. Jiao, J.; Li, Z.; Qiao, Z.; Li, X.; Liu, Y.; Dong, J.; Jiang, J.; Cui, Y. Design and self-assembly of hexahedral coordination cages for cascade reactions. Nat. Commun. 2018, 9, 1-8. [CrossRef] [PubMed]

195. Samantray, S.; Krishnaswamy, S.; Chand, D.K. Self-assembled conjoined-cages. Nat. Commun. 2020, 11, 1-11. [CrossRef]

196. Han, M.; Engelhard, D.M.; Clever, G.H. Self-assembled coordination cages based on banana-shaped ligands. Chem. Soc. Rev. 2014, 43, 1848-1860. [CrossRef] [PubMed]

197. Krisyuk, V.V.; Baidina, I.A.; Basova, T.V.; Bulusheva, L.G.; Igumenov, I.K. Self-Assembly of Coordination Polymers from Volatile $\mathrm{Pd}{ }^{\mathrm{II}}$ and $\mathrm{Pb}{ }^{\mathrm{II}} \beta$-Diketonate Derivatives through Metallophilic Interactions. Eur. J. Inorg. Chem. 2013, 2013, 5738-5745. [CrossRef]

198. Groom, C.R.; Bruno, I.J.; Lightfoot, M.P.; Ward, S.C.; IUCr. The Cambridge Structural Database. Acta Cryst. Sect. B 2016, 72, 171-179. [CrossRef] [PubMed]

199. MacRae, C.F.; Sovago, I.; Cottrell, S.J.; Galek, P.T.A.; McCabe, P.; Pidcock, E.; Platings, M.; Shields, G.P.; Stevens, J.S.; Towler, M.; et al. Mercury 4.0: From visualization to analysis, design and prediction. J. Appl. Cryst. 2020, 53, 226-235. [CrossRef] [PubMed]

200. ACD/ChemSketch, Version 2018.1.1 2019; Advanced Chemistry Development Inc.: Toronto, ON, Canada, 2019. 